NBER WORKING PAPER SERIES

\title{
DID BIG GOVERNMENT'S LARGESSE HELP THE LOCALS? THE IMPLICATIONS OF WWII SPENDING FOR LOCAL ECONOMIC ACTIVITY, 1939-1958
}

\author{
Joseph Cullen \\ Price V. Fishback \\ Working Paper 12801 \\ http://www.nber.org/papers/w12801 \\ NATIONAL BUREAU OF ECONOMIC RESEARCH \\ 1050 Massachusetts Avenue \\ Cambridge, MA 02138 \\ December 2006
}

We would like to thank Todd Sorensen, Trevor Kollman, Jennifer Yelle, Bill McNerney, Peter Vu, Doug Larue, Josh Easterlin, and Allison Johnson for their invaluable help in organizing and computerizing the data. We are grateful to Martin Feldstein and the National Bureau of Economic Research for financial support of this project. The National Science Foundation provided grant support to fund collection of the data from the New Deal project used in this paper. Any analysis and interpretations in the paper should not be seen as representing the views of those organizations. We received invaluable advice on earlier versions of this paper in presentations at the University of Arizona Economics Department, University of Wales at Swansea, Warwick University, Lehigh University, Columbia University, Oxford University, Seoul National University, the 2007 Economic History Association Meetings, and from the following people: Manuela Angelucci, Stephen Broadberry, Alan Dye, Alphonso Flores-Lagunes, Robert Higgs, Kei Hirano, William Horrace, Shawn Kantor, Ronald Oaxaca, Anthony O’Brien, Paul Rhode, Todd Sorensen, Bishnupriya Gupta, Knick Harley, John Treble, Jane Humphries, Richard Sutch, Richard Sylla, and John Wallis. The views expressed herein are those of the author(s) and do not necessarily reflect the views of the National Bureau of Economic Research.

(C) 2006 by Joseph Cullen and Price V. Fishback. All rights reserved. Short sections of text, not to exceed two paragraphs, may be quoted without explicit permission provided that full credit, including $\odot$ notice, is given to the source. 
Did Big Government's Largesse Help the Locals? The Implications of WWII Spending for Local Economic Activity, 1939-1958

Joseph Cullen and Price V. Fishback

NBER Working Paper No. 12801

December 2006, Revised January 2008

JEL No. H50,N32,N42,N92,R11

\begin{abstract}
$\underline{\text { ABSTRACT }}$
Studies of the development of local economies often point to large-scale World War II military spending as a source of long-term economic growth, even though the spending declined sharply after the demobilization. We examine the longer term impact of the temporary war spending on county economies using a variety of measures of socioeconomic activity: including per capita retail sales, the extent of manufacturing, population growth, the share of women in the work force, housing values and ownership, and per capita savings over the period 1940-1950. We find that in the longer term counties receiving more war spending per capita during the war experienced extensive growth due to increases in population but not intensive growth, as the war spending had very small impacts on per capita measures of economic activity.
\end{abstract}

Joseph Cullen

University of Arizona

jcullen@email.arizona.edu

Price V. Fishback

Department of Economics

University of Arizona

Tucson, AZ 85721

and NBER

pfishback@eller.arizona.edu 


\title{
Does Large-Scale Military Spending Stimulate Local Economies? The Implications of WWII Spending for Local Economic Activity, 1939-1958
}

\author{
Joseph Cullen and Price Fishback
}

Many histories of state and local communities credit the influx of large amounts of federal military spending during World War II as a transformative episode that led to long-run economic growth despite the short run nature of the spending. The descriptions of thriving communities and expanding manufacturing suggest that there was extensive growth in areas with high military spending. But was the extensive growth they describe just a sign of expanding populations or did per capita measures of economic activity rise as well? Was the War spending also associated with greater shifts in the local economies toward greater manufacturing, greater savings, and more roles for women? We examine the longer term effects of the rise and fall in local military spending during World War II on economies at the county level in the United States by examining the changes between 1939 and the late 1940 s and the 1950s in a variety of measures of economic activity. The answers to these questions likely provide useful information for modern policy makers as well, as many communities have experienced expansions and declines in federal military spending over the past several decades.

We focus on the most dramatic rise and fall in military spending in American history, the decade of the 1940s. At its peak in 1944, military spending accounted for over forty percent of Gross Domestic Product, receding to about 5 percent by 1950 . Nearly all of the discussions of the War's economic impact in America have focused on macroeconomic aggregates before, during, and after the war. The general public and many standard history texts still cling to a macroeconomic story that describes World War II as a Keynesian stimulus that brought us out of the Great Depression. However, 
Robert Higgs (1992, 1999, 2004, 2006), building on the work of Simon Kuznets (1945) and others, shows that more accurate measures of real consumption fell during the war, unemployment was eliminated largely by drafting people into the military, and that the primary pure economic benefit of the War might have been to improve expectations for the future. ${ }^{1}$ Despite predictions of a post-War recession by contemporary Keynesians, the long-suppressed consumer and investment demand burst forth into a macroeconomic boom following the War.

We do not address the macroeconomic question of whether there was a uniform stimulus or slowing nation-wide. Further macroeconomic analysis of the war in the U.S. is limited by several factors. There are only a few data points, and there are significant conceptual measurement issues associated with the transition to and from a command economy. Standard market-based measures of economic activity are not designed well to deal with situations in which prices and allocations were largely determined by central planners, consumers could not purchase a many goods that are normally available, and face significant rationing of other goods.

We focus instead on whether community leaders would have found it beneficial in the longer run for their community to compete in the political arena for federal war spending. ${ }^{2}$ To avoid many of the conceptual difficulties of measurement of welfare under the command economy we examine various aspects of the economy in 1939, just prior to the military buildup, and again in the late 1940s and in some cases in the 1950s,

\footnotetext{
${ }^{1}$ The benefits from the War were largely geo-political. The allied victory prevented the tyranny of a western Europe controlled by Hitler and Mussolini and a militaristic regime under Japan in Asia. These results aided economic freedoms and growth and international trade in western Europe and Japan, although large swaths of the world's population were now subject to the mercy of Stalin's USSR regime.

${ }^{2}$ Rhode, Snyder, and Strumpf (2002) have recently addressed the political economy of the distribution of war spending.
} 
after the conversion back to the peace-time economy had been completed. To that end, we have combined information from a wide variety of sources into a data set that allows us to estimate reduced-form relationships between federal war spending per capita from 1940 through 1945 and various measures of the economic change in local economies from their positions before the war to a setting several years after the decline in the spending. To show the path of analysis, we start by examining the impact of war spending on local growth in retail sales per capita for the periods 1939-1947, 1939-1954, and 1939-1958. The early portion of the paper describes the military mobilization during World War II and shows the substantial variation in both war spending and retail sales growth across counties that is the source of identification of the relationship. We then show how the estimated reduced-form coefficient summarizes the combined effects of crowding out of local production, drags on growth from the federal tax rates on additional income, the shares of inputs for war production bought locally, and the shares of consumer incomes spent on locally produced goods and services. The coefficients are estimated with a variety of different control variables. A series of robustness tests of the results are performed using different sub-samples, instrumental variable estimation, and difference-in-difference analysis for retail sales per capita growth over the period 19391948, 1939-1954 and 1939-1958.

Similar reduced-form analysis is used to examine several other dimensions of economic activity that have received extensive comment in the narratives on World War II including savings, manufacturing, women in the workforce, and population growth. Changes in savings during and after the War are measured with per capita E-bond sales in 1944 and 1949, the growth in bank deposits per capita from 1936-1944 and 1936-1949, 
and growth in the percent owning homes and housing values from 1940 to 1950 . The impact on the manufacturing structure is measured with the change in the percentage employed in manufacturing from 1940 through 1950 and growth in manufacturing value added per capita from 1939 through 1947. The change in the share of women in the workforce and in the employment rate for women between 1940 and 1950 are used to capture the impact of military spending on women's roles in the labor force. Finally, the impact of the military mobilization on long-term population distribution is captured by the growth in population from 1940 to 1950.

The results show that the rise and fall in World War II spending in counties contributed to extensive growth in the longer run, but had virtually no effect on intensive growth. Greater WWII military spending in a county left the residents of the county no better off in per capita terms than the residing in counties without war spending. The dominant effect of greater War spending in a county was to raise population growth, as a substantial number of civilians moved to war production areas during the war and many stayed in the new location rather than incur the costs of a return migration. The War spending stimulated E-bond sales substantially and bank deposits to a small degree during the war. When the period is extended to 1949 , however, the relationship between war spending and these forms of saving were slightly negative. Similarly, changes in home ownership rates and median non-farm housing values were also slightly more negative in areas with more home spending. Greater war spending in a county had virtually no effect on decade-long growth rates in retail sales per capita, manufacturing annual earnings and labor productivity, and the share of manufacturing in the county. Consistent with the findings of Claudia Goldin (1991), areas with greater war spending 
experienced only a minor increase in the share of women in the workforce between 1940 and 1950.

The lack of a longer term effect of War spending per capita on consumption, savings, and earnings fits into the mixed set of findings in the literature on the impact of public works spending. ${ }^{3}$ There were specific features of the War spending that may have led to the lack of an effect. First, World War II spending largely replaced production of private consumption and investment goods. Second, there were significant short-run costs when factories that normally produced civilian goods were converted into war production facilities in the early 1940s and than were reconverted back to civilian production after the War. In a number of cases, war production facilities ended up as scrap because they could not be converted at reasonable cost to production of civilian goods (Higgs 2004). Finally, high federal tax rates that were paid by the majority of households imposed strong fiscal drags on any stimulation to income provided by greater War spending.

\section{WWII Economic Mobilization, Demobilization, and the Allocation of War Spending}

President Roosevelt initiated World War II economic mobilization nearly two years prior to the U.S. entry into the War, as military appropriations rose from $\$ 0.5$ billion in 1939 to $\$ 8$ billion in 1940 and $\$ 26$ billion in 1941 (Schubert 1994). Roosevelt established civilian mobilization agencies, like the War Production Board (WPB), that in

\footnotetext{
${ }^{3}$ Recent empirical work investigating the impact of civil infrastructure on economic growth gives mixed support to the hypothesis that more infrastructure spending leads to substantial increases in economic growth. See Aschauer 1989; Costa, Ellson, and Martin 1987; Duffy-Deno and Eberts 1991; Hulten and Schwab 1991; Garcia-Mila and McGuire 1992; Munnell 1992; Gramlich 1994; Fernald 1999; Fishback, Horrace, and Kantor $(2005,2006)$, and Pereira and Flores de Frutos 1999.
} 
theory were expected to oversee the massive transition to a military economy. Yet, most scholars agree that it was the military procurement agencies and not their civilian counterparts that wielded the power of allocation during WWII. The military decided where contracts were allocated with little interference from the WPB. Economic problems in counties received virtually no systematic consideration in distributing funds, although political considerations still held some sway. Speed of production almost always overrode all other considerations.. The sheer magnitude of the procurement effort and the necessity for speed led the army to contract with as few companies as possible and leave subcontracting up to the prime contractors. To expedite the process of procurement, contracts were placed by negotiation rather than competitive bidding. ${ }^{4}$ Firms with prior military contracts had a significant advantage in the process. ${ }^{5}$ In addition, the technological complexity of new war materials required significant engineering and manufacturing expertise that eliminated many firms from competition for contracts.

By 1942 consumers faced price controls and rationing of consumer goods as military objectives increasingly crowded out production for civilian consumption. Head of the WPB Donald Nelson noted that ".converting the automobile industry was, in a sense, destroying it" (Nelson 1946, 218). By 1944 military spending accounted for forty-four percent of GDP, a level never reached before or since. The production of consumer durables, like washing machines and electric appliances were restricted or prohibited altogether (Koistinen 2004, 279). Steel, aluminum, rubber, and numerous

\footnotetext{
$4 \quad$ Between July 1, 1939 and June 30, 1940, 87 percent of the War Department procurement was place using competitive bidding. In the following year between July 1, 1940 and February 28, 1941, 74 percent of purchasing to the form of negotiated contracts (Higgs, 1993)

${ }^{5}$ See Koistinen 2004, Smith 1959, Rhode, Snyer, and Strumph 2003; Higgs 2006, 91.
} 
other materials were primarily allocated to military production under the priority allocation system, increasing the difficulties for consumer product businesses, usually small, to operate. Approximately 43 percent of the nation's 184,000 manufacturing firms could not be used directly or indirectly for war production and could not be spared critical materials for nonessential output at even curtailed rates (Koistinen 2004, 278-9). ${ }^{6}$

After the official end of the war, the war industries rapidly demobilized. The day following the surrender of Japan on August 15, 1945, all controls over manpower were removed and ration restrictions on fuels were lifted. The remaining rationing orders (except for sugar) were lifted in succession by the end of 1945. Price controls were lifted in stages through 1946 and 1947. On the producers' side, the WPB eliminated most priority controls on input materials, over 2.5 million workers were released from war jobs, and almost one-third of the almost 300,000 outstanding war contracts had been canceled by the end of August (U. S. Bureau of Budget 1946, 492\}. Many businesses then went about the process of converting back to production of consumer goods. Despite predictions that the declines in war spending would lead to a major recession, the return to peace led to a rapid expansion in business investment, private employment, and private production (Higgs 1999, 2004, 2006). A significant part of this investment involved reconverting to a civilian economy. The extent to which war plants could be effectively converted to civilian production varied by industry. Some firms who could take advantage of plentiful war contracts and federal tax incentives for plant expansion

\footnotetext{
6 Donald Nelson (1946, 269), chair of the WPB, recognized this dichotomy. "I hope that a little repetition will serve to underscore my acknowledgment that business firms of sub-average size , more often than not, did get the dirty end of the stick....The difficulty was, we didn't quite know how to utilize the thousands and thousands of small firms which were beginning to be pinched because of the purchases of goods and raw materials by the large manufacturers."
} 
had significantly improved their facilities at the war's end. Many repairs and improvements were made to facilities that had fallen into partial disrepair during the Depression. However, Robert Higgs (2004) found that the bulk of the government investment was too specific to military production needs to be useful for consumer goods after the war.

\section{The Geography of War Spending and Economic Activity}

The geographic allocation of war contracts was concentrated due both to firm behavior and the needs of military planners. Planners divided war spending into two broad categories: contract spending and facilities spending.

Contract spending, which accounted for the bulk of all war spending, included the value of all supply contracts with value of $\$ 50,000$ or higher that were awarded by major procurement branches of the military to individual producers for the procurement of combat supplies such as planes, tanks, guns or ships, as well as incidental materials like clothing, medical supplies, and paper. The value of contracts reported in our analysis reflects the net value of contracts with any contract cancellations or contract reductions having been subtracted. The bulk of the contract awards by value went to combat equipment such as flight planes, tanks and ships. By value approximately 65 percent of total contracts went to combat equipment.

Facilities spending, defined as funds used to build government financed military or industrial facilities, accounted for only 13 percent of total war spending in 1940-45. ${ }^{7}$

\footnotetext{
${ }^{7}$ These were projects financed by the Army, Navy, Maritime Commission, Defense Plant Corporation, Reconstruction Finance Corporation, and British Empire governments with estimated value
} 
Although each had a different purpose, facilities and contract spending are so strongly correlated that concerns with multicollinearity make hypothesis tests on the separate types of spending difficult. Consequently, for this analysis all spending will be considered jointly under the term "war spending.'.

Spending for a particular contract was assigned to a county if the principal producing plant was located in the county. The contracting firms were generally large players in industry who were generally reluctant to subcontract to smaller firms except for the least profitable parts of the contract. As a result, contract funds remained largely where the prime contract was allocated. As the demand for military products grew, production was expanded at first using existing facilities. Eventually, as military demand exceeded productive capacity, facilities also had to be expanded. Industry revealed a strong preference for expanding existing facilities rather than setting up a new plant in a new location; most of the time the military did not challenge their decision (Koistinen 2004).

Because of the concentration of contracts and the concentration of facilities expansion, production therefore was concentrated in a relatively small number of firms and counties, especially early in the mobilization. As seen in the map of county level war spending in Figure 1, much of the war spending was highly concentrated in the heavily industrialized areas in the Northeast, along the Great Lakes, and the West Coast. Collectively, the top twenty counties accounted for almost 40 percent of total spending. At the top of the list are chiefly large industrial counties. Wayne County, Michigan, home of the Detroit automakers, accounted for 5.7 percent of the total. Los Angeles, California estimate of the final cost of the project. These included industrial facilities that produced war materials such as aircraft plants or shipyards and military installations such as air fields or cantonments. 
was number two with 4.9 percent and Cook County (Chicago), Illinois ranked third with 4.4 percent of total spending. Our data on war spending does not include information on the secret nuclear projects at Hanford, Washington, Oak Ridge, Tennessee, and Los Alamos, New Mexico. We eliminated the counties from the analysis because the projects carried on long after the war and did not display the rise and fall seen in the vast majority of counties in the United States.

Spending in per capita terms was less concentrated as shown in Figure 2. The mean squared error (ratio of the standard deviation to the mean) of total spending was 6.5, which was nearly double the mean squared error of 3.6 for war spending per capita. Further, the per capita distribution in Figure 2 yields some different rankings. Sarpy County, Nebraska received the most spending per capita with approximately $\$ 144,771$ (1967\$) per 1940 resident from 1940 to 1945 . Located just south of Omaha, Sarpy had been home to the Army's Offutt Air Field since the early 1920s and in 1940 became the site of Glenn Martin's bomber assembly plant (Rhode, Snyder, and Strumpf 2002). At the bottom of the list, 43 percent of the 3065 counties in the US failed to receive even one dollar of war spending.

The central issue in the paper is the extent to which the rise and fall in war spending stimulated local economic activity over the medium run. We examine the impact of war spending on several dimensions of economic change over the 1940s. The most general measure of changing economic activity that we examine is the growth rate in retail sales per capita between 1939 and 1948. Therefore, we use the growth retail sales per capita as an example to show the analytical process that we follow for all of the variables. Fishback, Horrace, and Kantor (2005) used a similar measure in their 
examination of the impact of the New Deal on economic activity in the 1930s. County level measures of income are not available, and retail sales are very highly correlated with income and with consumption. In comparisons at the state level, where both are available, for example, retail sales and estimates of personal income have correlations above 0.87 for several years in the 1930 s.

The war prevented the collection of a retail census on the usual schedule; retail sales information was collected in 1939 before the start of the war and was not collected again until 1948. However, a focus on the 1939 and 1948 retail sales measures is advantageous even if intermediary data were available. Retail sales data from the war period of 1940-1945 would likely mis-measure the true normal market value of consumption due to the distortions caused by price ceilings, rationing, and black market transactions. These problems have plagued the estimates of consumption expenditures as a measure of consumer welfare during the War Years (Higgs 1992). By 1948 price controls and rationing were one to two years in the past, and the industries had reconverted to peacetime production. Hence, our estimates of the impact of WWII spending on retail sales reflect not the immediate effect, but the medium run consequences of war spending which occurred after the economy was allowed to readjust to civilian production.

Figure 3 shows the state growth rates in retail sales per capita plotted against war spending per capita. Retail sales per capita grew rapidly between 1939 and 1948. Most states experienced growth rates of above 65 percent with the lowest rates in Massachusetts at 36 percent. There appears to have been a slight negative relationship between war spending and retail sales, which we will explore in much greater depth 
econometrically. Connecticut and Michigan had the greatest per capita war spending at over $\$ 10,000$ per person, but their growth rates in retail sales were in the lower part of the state distribution. Meanwhile, a number of farm-oriented states experienced high retail sales growth while receiving much less war spending.

Although there was substantial variation at the state level, the variation was even greater at the county level. The map in Figure 4 shows the range of growth rates in economic activity at the county level. As seen in the state scatter plots, the highest rates of retail sales growth per capita were found in the farm belt. Comparisons of Figures 1 and 2 and 4 show again that the highest concentrations of war spending were generally not associated with the highest growth rates in per capita retail sales. There are a variety of reasons why this negative relationship appears in simple correlations. For example, many of the high growth areas were areas with low levels of retail sales per capita as of 1939. Thus, the same dollar increase in retail sales per capita would generate higher growth rates for those counties than for counties with higher 1939 levels. We will control for prior levels and a variety of other factors in the econometric analysis.

\section{Predicting the Effect of World War II Spending on Local Economies.}

The natural expectation is that the introduction of World War II contracts and facility spending during the War would have led to expansions in the local economy that might have carried over after the war and led to faster growth over the entire decade of the 1940s. In late 1940, the unemployment rate was still hovering around 10 percent, so it would appear that the war spending would help soak up that unemployment. Fishback, Horrace, and Kantor (2005) find that an additional dollar of New Deal public works and 
relief spending between 1933 and 1939 led to an increase in retail sales of roughly 43 cents in retail sales per capita in 1939, which they suggest can be translated into an expansion of income of over 80 cents in 1939. It is important to note, however, that the New Deal public works and relief spending were on roads, dams, and other public projects and were not meant to take the place of private production. There may have been some crowding out of private employment, as found by Wallis and Benjamin (1989), but this was more indirect.

The war contracts and facilities had much stronger and direct crowding out effects because privately-owned plants that normally produced autos, clothing, and consumer goods were converted to produce military equipment. Kuznets (1945) and Higgs (1992, 1999) document sharp declines in the production of many consumer goods associated with this conversion. In addition, there were the added costs of converting from consumer to military production at the beginning of the war and then the conversion back after the war had ended. We should not anticipate, however, that the crowding out would necessarily be one for one, because the plants converted likely were increasing total production, there were new facilities built, others were expanded, and the conversion may have led to technological updates that raised productivity.

Our goal in the paper is to estimate a reduced-form coefficient that summarizes a group of effects of the change war spending on changes in retail sales at the county level. We believe it would be valuable to identify the individual effects on these multiple relationships, but data limitations force us to ask the much simpler question, what was the overall medium run impact of World War II spending at the local level? As a political economy question, we are asking would it have been a good move for state and local 
community leaders to push strongly to try to obtain war spending that they knew would be temporary to enhance the relative economic welfare of their communities? .

Our construction of the underlying factors incorporated in the reduced-from coefficient builds on a series of identities inspired by a model of fiscal federalism developed by Wallace Oates (1973, 22-29). It is based on a regional model in which citizens consume a mixture of goods produced inside and outside their counties and export and import goods from other counties. Since we are interested in showing the impact of an additional dollar of WWII spending on the growth rate of retail sales, we develop this discussion in terms of changes in the relevant variables. In the course of the section, we show that changes in all of the variables are influenced to some degree by changes in World War II spending, so the reduced-form impact of World War II spending is obtained through a series of algebraic substitutions. The ultimate goal of the substitutions is to end up with the change in retail sales as a function of the change in World War II spending and the reduced-form parameter, holding other factors constant. All monetary variables discussed below are assumed to be in per capita terms.

Increases in after-tax income cause increases in the demand for goods (retail sales), which lead to increases in the total revenue of retail sales, assuming an upward sloping or flat supply curve in the retail market. Thus, the relationship between changes in retail sales and changes in after-tax income can be expressed as

$$
\Delta R_{i}=r\left(1-t_{f}\right)\left(\Delta Y_{i}-\Delta T_{i s l}\right)
$$


where $i$ indexes the county, $\Delta R_{i}$ is the change in retail sales, $r$ is the share of disposable income devoted to retail sales, $\Delta Y_{i}$ is the change in income, $t_{f}$ is the federal income tax rate, and $\Delta T_{i s l}$ is the change in lump-sum state and local taxation, which is assumed to be tax deductible for federal tax purposes.

The change in county $i$ 's income can be written as the sum of the following changes:

$$
\Delta Y_{i}=\Delta P I_{i}+\Delta X_{i}-\Delta M_{i}+\Delta W_{i}+\Delta S L_{i}
$$

where $\Delta P I_{i}$ is the change in private spending within the county on goods and services produced within the county, $\Delta X_{i}$ is the change in private income from non-war production exported outside the county, $\Delta M_{i}$ is the change in goods and services imported from outside the county, $\Delta W_{i}$ is the change in War spending and $\Delta S L_{i}$ is the change in state and local government spending. ${ }^{8}$

The change in private spending on goods and services produced within county $i$, $\triangle P I_{i}$, is influenced by changes in after-tax disposable income,

$$
\Delta P I_{i}=\gamma\left(1-t_{\mathrm{f}}\right)\left(\Delta Y_{i}-\Delta T_{i s l}\right)
$$

where $\gamma$ reflects the share of after-tax income allocated to employing unemployed resources and purchasing local goods in county $i$. The change in goods imported from

\footnotetext{
$8 \quad$ For the purposes of this exercise, we are assuming that all other federal government spending has stayed constant.
} 
outside the county, $\Delta M_{i}$, is influenced by changes in disposable income and in war spending,

$$
\Delta M_{i}=m\left(1-\mathrm{t}_{\mathrm{f}}\right)\left(\Delta Y_{i}-\Delta T_{i s l}\right)+m_{\mathrm{s}} \Delta S L_{i}+m_{\mathrm{w}} \Delta W_{i,}
$$

where $m$ denotes the share of additional after-tax income that county residents used to purchase goods and services outside the county. Similarly, $m_{\mathrm{s}}$ and $m_{\mathrm{w}}$ are shares of state/local and War outlays, respectively, that government decision-makers devoted to purchases from outside the county. ${ }^{9}$

Private income from non-war goods sold outside the county, $\Delta X_{i}$, might also have been influenced by changes in World War II outlays, such that

$$
\Delta X_{i}=\pi \Delta W_{i}
$$

The $\pi$ parameter reflects the extent of crowding out or expansions in productivity associated with the war spending. If there were full one-for-one crowding out of private production, then $\pi=-1$. If we add conversion costs coming into and out of the war, $\pi$ could even be more negative than -1 . These crowding out effects would be offset by any productivity increases and expansions of facilities. If the productivity rise fully offset the crowding out, $\pi=0$. It is more likely that the parameter is between 0 and -1 .

\footnotetext{
$9 \quad$ Note that after substituting equation 2.4 into equation 2.2, the impact of an added dollar of New Deal spending on local income is $\left(1-m_{\mathrm{n}}\right)$ and that of another dollar of state and local spending is $\left(1-m_{\mathrm{s}}\right)$. We do not include government spending in the private consumption of internal county production because it would lead to double counting. The sum $m+\gamma$ would equal one if there were no saving.
} 
An influx of federal spending can lead to responses by state and local governments, so we assume the functional relationship

$$
\Delta S L_{i}=\theta \Delta W_{i}
$$

Increased War spending might have led state and local governments to spend more on roads and infrastructure $(\theta>0)$ to sustain the increased activity around the plants. On the other hand, cuts in unemployment would have reduced the extent to which the governments were required to provide public assistance $(\theta<0)$. In either case, the effects on state and local spending were likely to be offset by changes in state and local taxation.. As a result, we specify

$$
\Delta T_{i s l}=\delta \Delta S L_{i}
$$

Substituting equation (2.6) into (2.7) yields

$$
\Delta T_{i s l}=\delta \theta \Delta W_{i}
$$

State and local governments faced significant state constitutional restrictions in their ability to run short run deficits. Even when the governments ran temporary deficits, however, the bulk of the bonds were sold in markets outside the local jurisdiction and thus repayment of the debt at market interest rates was likely to be expected. Thus, a close to balanced budget ( $\delta$ near or $=1)$ assumption, where increases in state and local 
spending are matched or nearly matched by increases in state and local taxation, is reasonable. To the extent that state and local governments had more leeway to run deficits and obtain subsidized interest rates, $\delta$ might be assumed less than one. ${ }^{10}$

We can obtain a reduced-form equation with the change in retail sales as a function of the change in War spending by substituting from equations 3, 4, 5, 6, and 8 into the change in income equation (2). Equation 2 can then be rewritten as the change in income as a function of the change in war spending and all of the parameters. We then can substitute from the new version of equation 2 into the retail sales equation (1), which then yields:

$\Delta R_{i}=r\left(1-t_{f}\right)\left[1 /\left(1-\left(1-t_{f}\right)(\gamma-m)\right)\right] *\left[1-m_{\mathrm{n}}+\pi+\left(1-m_{\mathrm{s}}-\delta\right) \theta\right] \Delta W_{i}$

Define $\Pi$ to be the base multiplier, which is the first half of the term in equation (9):

$$
\Pi=\left(1-t_{\mathrm{f}}\right) /\left[\left(1-\left(1-t_{\mathrm{f}}\right)(\gamma-m)\right]\right.
$$

The base multiplier increases in value as the share of extra spending on purchases of unemployed local resources and local goods and services $(\gamma)$ produced inside the county rises and as the share of goods and services imported into the county $(m)$ falls. Higher federal taxes will reduce the size of the multiplier. Thus, the federal tax rates serve as

10 See Oates 1973. During the 1930s, all of the states ran very large surpluses if capital outlays are excluded from their budgets. The inclusion of capital outlays led to deficits in twothirds of the states. The states appear to have taken repayment of their debts seriously because by 1937 all but four states ran surpluses (including capital outlays as spending), some of which were very large, and three of the remaining four were very close to a balanced budget (U.S. Bureau of the Census 1935, 8-17, 28-39; 1940, 7-16). 
drag on the benefits of expansion in the local economy and the income multiplier is reduced. Estimates of base multipliers for employment with more recent county-level data suggest values ranging from 1 to 2.5 (Vias and Mulligan 1997). ${ }^{11}$

Let $\mu$ be the reduced-form relationship measuring the impact of an additional dollar of War spending in county $i$ on retail sales. That is,

$$
\beta=r \Pi\left[1-m_{w}+\pi+\left(1-m_{\mathrm{s}}-\delta\right) \theta\right]=r \mu
$$

The reduced form parameter $\beta$ summarizes the various channels through which war spending influenced retail sales and $\mu$ is the income multiplier after all influences are accounted for. To get a sense of what might be reasonable values to expect for $\beta$ and $\mu$, Table 1 shows how different values of the key parameters would affect the impact of World War II spending on retail sales. Although the reduced-form parameter is composed of several underlying parameters, we can make educated guesses about some of their values, while others have very little impact on the predicted value of $\beta$.

In general, we have a good sense of the following parameter values. Estimates from national data suggest a ratio of retail sales to personal income of roughly 0.53 . If the income elasticity for retail sales was one, we can reasonably assume that the $r$ will remain the same for different income levels. Alternative income elasticities suggest that the range of the ratio for income levels 20 percent above or below or the mean would be within the range of .5 to .6. If we find that an additional dollar of war spending raised

11 For discussions of the theoretical bases for these multipliers, see McGregor, et. al. (2000), Merrifield (1987), and the sources cited therein. The multipliers based on neoclassical principles have assumed that labor markets clear at the prevailing wage. We chose a quasiKeynesian approach in part for simplicity and in part because of the strong price controls that prevented the existence of market clearing prices during the war years. 
retail sales by .53 , it would suggest that income in the county rose by approximately one dollar, i.e. an income multiplier $(\mu)$ of 1 . It is possible that the marginal $r$ might differ from the average $r$. As $r$ increases toward 1, so that each additional dollar of income goes to retail sales, the income multiplier converges to the retail sales coefficient. As $r$ falls, the income multiplier from the retail sales coefficient rises.

In Table 1 we assume a nearly balanced state and local government budget, $\delta=$ 0.9 , and that the War spending had a net effect of increasing state and local spending $(\theta=$ 0.1). Changes in the state and local government crowding or matching parameter $\theta$ have little effect on the reduced-form coefficient because state and local governments faced restrictions on deficit spending. If state and local governments had balanced budgets and focused their spending on goods and services produced inside the county, $\delta=1$ and $m_{\mathrm{s}}=$ 0 , the estimated coefficient will reflect no flypaper or crowding-out effects. A reasonable assumption can be made that state and local governments focused their spending on local workers and goods and services, such that only 20 percent of state and local government spending went toward the purchase of goods and services from outside the county $\left(m_{\mathrm{s}}=0.2\right)$. Changes in this assumption also tend to have very small effects on the final reduced-form parameter.

Everybody in the U.S. faced the same federal tax schedule, and taxation increased dramatically during the war. For the first time the majority of the households paid income taxes. We are assuming that corporate income taxes are being paid in the counties where the plants were located, as well. The ratio of federal tax revenues collected to GDP was 0.10 in 1942, 0.23 in 1944 and 0.21 in 1946, so we choose a figure of 20 percent to reflect the extent of taxation. Lowering the tax rate to 10 percent 
compared to the baseline with half crowding out in Table 1 raises the retail sales coefficient from 0.13 to 0.16 .

The anticipated retail sales coefficient $(\beta)$ is most strongly influenced by three parameters: the shares of income spent on local goods and services from outside the county $(m)$, the extent of crowding out or productivity enhancement of private activity $(\pi)$, and the extent to which the war spending was spent on inputs brought in from outside the county as opposed to wages, rents and other local services $\left(m_{w}\right)$. Table 1 shows the effects of different assumptions for these parameters. When the local/external spending split rises from 50/50 in the bottom half of the table to 75/25 in the top half, the base multiplier rises 1.67 fold. As a result the retail sales coefficient is magnified by the same ratio.

The extent of crowding out of local activity $(\pi)$ and the share of war plant expenditures purchased from outside the county $\left(m_{w}\right)$ serve to reduce the coefficient in a similar fashion. Both effects are magnified by the base multiplier. Given the structure of the relationship in equation 11 , the same change in shares has the same effect in both cases. In the first line of Table 1 , when the crowding out parameter $\pi$ is -0.5 and the share of inputs from outside the county at the war plant $\left(m_{w}\right)$ is 0.3 , the retail sales coefficient is only 0.13 . Increasing the absolute magnitude of the crowding out parameter $(\pi)$ from -0.5 to -0.7 in line 2 has the same effect as increasing the external share of inputs used for war spending $\left(m_{\mathrm{w}}\right)$ from 0.3 to 0.5 . Each reduces the reducedform retail sales coefficient $(\beta)$ from 0.13 to -0.1 . If the war had added production with no replacement or increased productivity from the war spending had offset the crowding 
out, the $\pi$ parameter would be 0 . In that case, the retail sales coefficient $(\beta)$ would be 0.49 .

Therefore, even in the most optimistic scenario with no crowding out and large shares of consumption and war production spent locally, we should expect no more than a 50 cent increase in retail sales per capita for a dollar increase in per capita war spending during the years when the war spending occurred. Given the likelihood of significant crowding out of private production at the plants, we might expect no effect at all. The fiscal drag of the tax revenues collected on the expansion in income, the possibility of leakages in war spending when the plant brings in inputs from outside the county, and the possibility that war spending crowded out half of private production makes the possibility of a negative coefficient a real possibility.

Theoretically we have modeled what might have happened in the period during which spending took place. This differs from our empirical estimates, which examine the longer run effect of the military spending that includes not only the war spending years, but also the several years that followed. If war spending induced a rise in retail sales per capita during the war, there is the possibility that it could have been sustained after the war. However, the costs of reconverting to private industry after the warwould likely have slow retail sales growth after the war. Thus, the longer term effect would have been less positive than the immediate effect that might have occured during the war.

\section{Estimation Procedure}


We follow the lead of Fishback, Horrace, and Kantor (2005) in estimating a loglinear growth equation to estimate the impact of war spending on the change in retail sales between 1939 and 1948.

$\ln \left(\mathrm{R}_{\mathrm{i} 48}\right)-\ln \left(\mathrm{R}_{\mathrm{i}, 39}\right)=\beta_{0}+\beta_{1} \mathrm{WAR}_{\mathrm{i} 40-45}+\beta_{2} \ln \left(\mathrm{R}_{\mathrm{i} 39}\right)+\beta_{3} Z_{i 39}+\beta_{4} S+\varepsilon_{\mathrm{i}}$

where $\ln \left(R_{i} 48\right)$ and $\ln \left(R_{i, 39}\right)$ are per capita retail sales in 1948 and $1939, W^{\prime} A R_{i 0-45}$ is per capita war spending from 1940 through $1945, Z_{i 39}$ is a vector of structural correlates measured in 1939 that might have determined economic growth over the decade, $S$ is a vector of state dummies, and $\varepsilon_{\mathrm{i}}$ is an unobservable error term.

As in the Fishback, Horrace, and Kantor paper (2005), the vector of structural correlates includes a large set of variables measuring the economic, demographic and geographic composition of each county. The reason for including a large set of control variable is to avoid problems stemming from omitted variables that would lead to biased coefficients and incorrect inference about the impact of war spending on local economies. For expositional ease, the vector of correlates is further subdivided into the following categories: prior levels of retail sales, economic trends, demographic, geographic, climatic effects and states fixed effects.

$\left(Z_{i 39} S\right)=\left(\ln \left(R_{i 39}\right) E \operatorname{con}_{i 39}\right.$ Demo $_{i 39}$ Geo $\left._{i 39} \operatorname{Clim}_{\mathrm{i} 39} \mathrm{~S}\right)$

The model includes the lagged log level of retail sales per capita, as in most growth models to control for convergence and the mechanical negative relationship between 
growth rates and prior levels. To control for prior economic trends, the growth rate of retail sales from 1929 to 1939 is included. A series of demographic correlates control for differences in retail consumption patterns and income levels by age, race, ethnicity, education, gender, urbanization, and wealth ${ }^{12}$. Geographic features influenced the natural resource base, access to transportation, potential agglomeration economies, and other factors (Diamond 1997; Gallop, Sachs, and Mellinger 1999). We include weather information to control for the impact of both regular weather and extremes in weather that might have influenced building projects. These features were interacted with the share of farming because weather likely had stronger effects on agricultural output. Finally, we incorporated state fixed effects to control for factors that were common to all counties within a state but varied across states, including state taxes. The state dummies will capture unmeasured heterogeneity such as the extent of mobilization of the population into the armed forces, state taxation and revenue policies, retail laws, and differences in the cost of living across states.

Ordinary Least Squares estimates of the coefficients on war spending are shown in Table 2 for a series of specifications that add each set of correlates cumulatively. The simplest OLS specification,(1) shows the descriptive relationship between retail sales growth and war spending without any controls. As seen in the maps and scatter plots, there is a negative and statistically significant correlation between war spending and retail sales growth. A one standard deviation increase in war spending was associated with a reduction in the retail sales per capita growth rate of 0.19 standard deviations. ${ }^{13}$ The

\footnotetext{
${ }^{12}$ We use the share of the population which owns a radio as a proxy for the overall wealth of the county. 13 The standard deviation of county level war spending per captia is $\$ 4847$. The standard deviation of retail sales growth is 0.218 . Using the war coefficient in specification (1), we have $-8.54 \mathrm{E}-06$ times $4847=-0.041$ which is the effect of a one standard deviation change in war spending on retail sales growth.
} 
coefficient implies that at the average level of retail sales per capita in the U.S. in 1939 of \$557, a dollar increase in war spending per capita would have reduced retail sales per capita in 1948 by less than one cent. ${ }^{14}$ So the effect is relatively small.

Each subsequent specification in Table 2 retains the correlates of the previous specification while adding additional control variables. Although the coefficient remains statistically significant and negative, the addition of more correlates erodes the magnitude of the negative economic impact of the war spending. The OLS coefficients in specification 7 are reported in Table 4.

\section{Exploring Other Methodologies}

The results thus far suggest that a mixture of crowding out of private production, fiscal drag of taxation, leakages of military input spending, and/or consumption of goods produced external to the county contributed to war spending having virtually no effect on the local economies. We follow a series of procedures to examine the robustness of these findings, including estimations on subsamples, estimation of a simple 0 - 1 treatment effect, and the inclusion of agricultural output. Although all of the narrative evidence suggests no reason to anticipate endogeneity caused by the military trying to spend more in regions with high unemployment, we explore an instrumental variable analysis using the 1930s war preparation plans as an instrument. We also estimate a difference in

Dividing by the standard deviation of retail sales growth gives us the change in terms of the standard deviation, $-0.041 * 0.218=-0.19$.

${ }_{14}$ In specification (1), a $\$ 1$ increase in annual, per capita war spending in a county would reduce the difference between log retail sales in the later period and the log retail sales in the earlier period by 0.00000854 . At the average level of retail sales per capita in the US in 1939 of $\$ 533$ (the log value is 6.2785 ) this translates into a $\$ .0046$ decrease in retail sales for every war dollar spent in that county. 
difference model, where we examine the change in retail spending growth from 1929-39 to $1939-1948 .^{15}$

\section{Subsamples}

One potential worry with this data set is that the tremendous variation in the amount of war spending across counties includes outliers are driving the results. The impact of war spending per capita in specifications (8) through (11) in Table 3 show the results of checking the sample for outliers. After selecting a subsample from the full set of counties, each is estimated by OLS using the full set of correlates in specification (7).

Specification (8) eliminates counties which lie in the top 5\% in terms of war spending per capita, an average of $\$ 5028$ per capita. These were the most industrialized counties in the country. In gross terms the top 5\% of counties received 72 percent of the $\$ 493$ billion in contract war spending while accounting for only 26 percent of the population. Our goal in this specification is to compare the impact of the war spending in the counties which received nothing to those that received a moderate amount on the grounds that they are more alike.

Specification (9) considers only counties that received a strictly positive amount of war spending in case counties receiving no spending were too structurally different from those who received it.

Specification (10) still considers only counties with positive spending, but further eliminates counties in the tails of the positive spending distribution. Counties that are

\footnotetext{
${ }^{15} \mathrm{We}$ have also performed the complete analyses in the paper by adding a squared term for war spending per capita and by using natural logs of war spending per capita after adding a dollar to all values to eliminate zeroes). The qualitative findings are unchanged.
} 
below the $5^{\text {th }}$ percentile or above the 95 percentile in the positive spending distribution are removed.

Specification (11) addresses the implicit assumption made by OLS concerning common support. Problems with common support occur when there are no "similar" observations to use as a counterfactual. We are concerned that counties that received war money were systematically different from those that did not receive money after controlling for observable characteristics. For comparison purposes we are looking for counties that are similar along many characteristics but one does not receive spending while the other does. To examine the common support a dummy variable was created for receiving a positive amount of war spending. A probit model was used to estimate the probability of treatment, i.e. receiving greater than $\$ 0$ of spending on the full set of correlates in specification (7) of the OLS regression. A histogram of treated and untreated counties by propensity score was used to determine a "thick region" of common support. Treated counties in this thick region have as counterfactuals untreated counties with similar observable characteristics. Counties with a propensity score outside of the thick region were eliminated. The model was then estimated using OLS with the continuous measure of war spending and all structural correlates.

The results in Table 3 for the different subsamples tell the same story as before. There is a very small negative effect of war spending in each subsample, although several estimates are now statistically insignificantly different from zero.

\section{Treatment Effects}

Another hypothesis is what really matters is not how much war money is spent in your county, but simply if a county receives any money at all. Since nearly $40 \%$ of the 
sample received no war spending, we can run regressions with a balanced number of treated and control counties. For specification (12), we replace war spending per capita in specification (7) with a dummy variable equal to one if a county received any level of spending. The resulting coefficient on the treatment dummy is still small, negative and insignificant, very much in line with the previous results.

\section{Agricultural Production}

There were numerous reports of a sharp rise in agricultural production as American farmers grew foodstuff that were transported and sold to allies in war-torn lands. This rapid growth is highlighted in the county map for retail sales per capita growth in Figure 4. As seen in the other maps, these many farm counties did not receive much in the way of war spending. Specification (13) incorporates the growth in the value of farm output as a correlate. While the growth in farm output has a positive coefficient, the impact of war spending per capita remains negative, although smaller than in almost all of the other specifications.

\section{Instrumental Variables}

Another possible criticism of the OLS results is the potential endogeneity of war spending and retail sales. The allocation of war spending was not random: there is the possibility that it was endogenous. In order to have a negative endogeneity bias, war funds would have had to have been increasingly allocated to counties experiencing economic hardship. If military procurement plans took this into consideration, then the allocation of war funds to economically distressed counties could make it appear as though war spending impeded economic growth. 
A negative endogeneity bias is consistent with the following argument. The massive mobilization of the US economy caused labor shortages in areas with highly concentrated war spending by the middle of 1942. The shortages were exacerbated by the conscription of able-bodied workers. Meanwhile, civilian production by many smaller firms was squeezed by the lack of access to steel, aluminum, rubber and other necessary materials. In response to these economic disturbances, Critical Labor Areas and small business programs were developed to steer projects to smaller firms and areas with more unemployment. The narratives at the time, however, strongly state that the military, and not the War Production Board, dominated the allocation of the contracts, and the military paid little attention to these civilian-focused programs (Koistinen 2004). The programs generally had relatively few dollars to allocate but at the margin they might have influenced the distribution process in ways that caused some negative endogeneity bias.

On the other hand, the case for a positive bias due to endogeneity seems equally if not more plausible. From historical documents we know that large firms, businesses with established production records, and firms with manufacturing expertise had an advantage in acquiring contracts from military procurement agencies. Thus the most industrially capable and urbanized counties received the most war dollars. If we believe that economically capable counties also have characteristics that we have not measured that are correlated with a higher level of retail sale growth in the absence of contracts, then the allocation of war contracts to manufacturing counties would lead to a positive bias of our estimates of the impact of war spending. If we believe growth is more or less 
independent of the economic capacity of the county then this type of endogeneity is not an issue.

In either case, the situation warrants further inspection. A natural recourse in this situation is to use instrumental variables. To use this procedure, appropriate instruments must be found that are strongly correlated with per capita war spending, holding the other correlates constant, and also uncorrelated with the error term of the growth equation. We find one such set of instruments in the Industrial Mobilization Plan (IMP) of the 1930s.

The IMP was developed to avoid the shortcomings of the mobilization efforts during World War I. When the US entered World War I (WW I) in 1917, it had no stockpiles of equipment or already-laid plans for creating them (Schubert 1994). Competition between branches of the military for war supplies and inadequate flows of information led to price inflation, war profiteering, congestion and inefficient use of resources (Army and Board 1933, 1939). To avoid the problems during WWI, a series of military boards were established to plan and coordinate military production in time of war. Between 1931 and 1939 these boards established and revised IMPs based on surveys of the productive capacity of each firm. In the event of war the IMP plan assigned each plant a task to be performed for a specific branch of the military. The "more than ten thousand plants kept under allocation throughout the planning period represented the bulk, as well as the "cream" of American productive capacity (Smith 1959, 59)." Although the plan was never formally implemented during World War II, there is plenty of evidence that "the selection of contractors for most items was guided if not determined by the facility surveys and allocation plans of the previous decade."[cite] A 1943 study administered by the Army Industrial College in four major industrial cities 
found that 95 percent of contracts by value were awarded to facilities preselected under the allocation plan (Smith, 1959).

Given this institutional background, the number of facilities in a county allocated under the IMP seems to constitute an ideal instrument. The number of allocated facilities in a county was clearly correlated with placement of contracts in the county. Given that these allocation decisions were made well before the economic military mobilization, simultaneity bias is not a problem. The military planning process was designed to maximize readiness and thus was not oriented to potential unemployment in the 1940s.

To obtain counts, we use the last published directory of facilities which was published January 1, 1938, well before the US could anticipate the scale of the conflict to come. For each county the total number of facilities in the county allocated by the IMP was recorded. In addition, we count the number of facilities allocated to each procurement branch of the military. ${ }^{16}$ In practice the vector of instrumental variables was a subset of the allocations to particular procurement agencies or boards. We used the allocations to procurement agencies rather than the total number of facilities in a county due to heterogenous effects of different kinds of allocations. For example, the procurement agency with the highest number of allocations in most counties was the Army Quartermaster Corp. Yet the types of facilities allocated to this agency, such as clothing manufacturers or paper suppliers, were unlike to secure the high value contracts that facilities allocated to the Aeronautical Board were likely to obtain. A subset of

16 The sum of the number of facilities allocated to each procurement branch in a county is greater than or equal to the total number of allocated facilities in the county. This is because some facilities were shared by two or more branches of the military. Some "reserved" facilities were shared by all military branches and were officially allocated to either the Army Navy Munitions Board (ANMB) or the Office of the Assistant Secretary of War (OASW). Other facilities of strategic importance were made part of a special plan which had a separate board to manage their use. We note whether a facility was earmarked as part of a special economic mobilization plan. See Appendix Table I for a list of procurement agencies and special economic mobilization plan . 
counts by agency is used rather than the full set of counts by procurement agency because many of the counts lacked explanatory power in the first stage of estimation.

We re-estimate equation 12 using Two Stage Least Squares (2SLS) where the first-stage equation for war spending per capita contains all of the remaining right-hand side variables in equation 12 and the IMP counts. ${ }^{17}$ The first-stage and second-stage results, along with the OLS results and summary statistics for all variables are reported in Table 4. Each of the IMP counts had statistically significant effects on war spending per capita after controlling for the remaining correlates. The F-statistic for the identifying instruments as a group is 4.70. We anticipated that the Army Quartermaster Allocations would have a negative effect because of the small size of their contracts, but we did not expect the negative effects of the Steel Plan Allocations and the Office of the Assistant Secretary of War (OASW). As we examined the documents further, we discovered that there was a great deal of interactions between the various plans and the resulting multicollinearity makes it difficult to focus on specific coefficients. Although not all agency allocations are included in this regression, the negative signs on these instruments are still negative when all agency allocations are included. A Hausman overidentification test did not reject the null hypothesis that the identifying instruments are uncorrelated with the errors from the growth equation.

This is the first estimation procedure that has led to a positive coefficient. However, the coefficient is not statistically significantly different from zero. Further, the economic significance is tiny because an additional dollar of war spending raised the

17 Before discovering the IMP plans, we explored the use of a number of instruments, ranging from the political variables used by Fishback, Horrace, and Kantor $(2005,2006)$ to a series of variables used by Rhode, Snyder, and Strumpf (2002). In most cases they reduced the strength of the instruments, and in a number of cases their inclusion caused the Hansen test to reject the hypothesis that the specification was correct; thus there was a reasonable chance that the variables were correlated with the final equation error. 
level of retail sales by less than a cent and a one-standard deviation increase in war spending per capita raised the growth rate of retail sales per capita by 0.029 standard deviations.

\section{Differencing}

Our final robustness check involves estimating the differenced version of equation 12 with some adjustments that lead to equation 14 .

$$
\begin{gathered}
{\left[\ln \left(R_{i 48}\right)-\ln \left(R_{i, 39}\right)\right]-\left[\ln \left(R_{i, 39}\right)-\ln \left(R_{i, 29}\right)\right]=\alpha_{0}+\alpha_{1} W A R_{\mathrm{i} 40-45}-\alpha_{2} N D P R_{\mathrm{i}, 33-39}} \\
+\alpha_{3}\left[\ln \left(R_{i 39}\right)-\ln \left(R_{i 29}\right)\right]+\alpha_{4}\left[X_{i 39}-X_{i 29}\right]+\alpha_{5}\left[C_{39}-C_{29}\right]+\alpha_{6} S+\eta_{\mathrm{i}}
\end{gathered}
$$

The equation was developed by using information collected by Fishback, Horrace, and Kantor $(2005,2006)$ for their studies of the New Deal at the county level. There are several adjustments made. First, we include New Deal spending on public works and relief programs, which was the vast majority of federal spending in the 1930s. We don't have specific war spending for the 1930s, but we don't believe this to be problematic because annual military spending in the 1930s was less than one-twenty-sixth of the spending in 1942 and one-seventieth of the levels around 1944 (U.S. Census Bureau $1975,1120)$. Second, the differencing of the vector of correlates ( $Z$ in equation 12) between 1939 and 1929 drops the geographic variables because they do not vary over time and becomes the $\mathrm{X}$ vector of correlates in equation 14. Third, in differencing we might also expect that the state correlates will be differenced out, but we include them to capture the changes in policy and cost of living at the state level that might have 
influenced the changing growth rates. Fourth, AAA farm program spending was a key feature of the New Deal. The AAA continued and was reinforced in the 1940's (U.S. War Office of Budget, 1946). We have AAA information by county for the 1930s but not for the 1940s. To control for the AAA spending in both decades, we use the shares of crop output devoted to crops that were part of the AAA program in 1929 and in 1939 as proxies for the extent of AAA activity. ${ }^{18}$ Fifth, due to lack of information on retail sales growth per capita in the 1920s, we controlled for lagged growth in the X difference vector by using the difference in the growth rate of population between 1920-30 and $1930-1940^{19}$.

The differenced results are reported in Table 5. Again, we observe a negative and statistically significant effect of war spending that is very small in economic magnitude. We have explored using an instrumental variable analysis of the differenced equation but have been running into problems with finding instruments that are both strong in this setting and valid.

\section{Longer Range Effects on Retail Sales}

There is always the possibility that the medium term effects we have measured understate the longer-range benefits of the military spending because by 1948 the factories only recently had been converted. To check this hypothesis, we have also run the same sequence of estimates for growth rates in retail sales per capita from 1939 through 1954 and again for retail sales per capita from 1939 through 1958. The basic

18 The "big five" crops that received subsidies via the AAA were wheat, cotton, corn, tobacco, and rice. Of these five we control for four of these: wheat, cotton, corn, and tobacco.

19 The growth rate of the population seems to be a good proxy for retail sales growth. We found that substituting population growth for retail sale growth in the un-differenced model yielded almost exactly the same results. 
results in Tables 6 and 7 are very similar to what we have reported for the 1939-1948 period. All the War spending coefficients show virtually no relationship of the spending on the growth in retail sales per capita. All the coefficients are negative except in the 2SLS estimation. There may be some omitted variables issues in these two cases associated with spending for war production during the Korean War and the very beginnings of the building of the interstate highway systems after the act was passed in 1956. However, these expenditures were much smaller than the War expenditures and we do not believe them to have enough influence to alter the findings by much. ${ }^{20}$

\section{Accounting for the Lack of an Effect on Growth in Retail Sales Per Capita}

The finding of virtually no effect of war spending per capita on retail sales growth over one or two decades suggests that counties that never participated in the war contracting process experienced consumption gains that were similar in size to the consumption gains experienced in the War contracting counties. We can put the War spending findings into context by comparing them with the much positive stronger effects of public works and relief spending found by Fishback, Horrace, and Kantor (2006) in their study of the impact of New Deal spending on retail sales growth in the 1930s. Both studies estimated a reduced-form coefficient that simultaneously incorporates a variety of effects. There are three key differences between the War spending and the New Deal public works and relief spending that likely led to this result. First, the war spending explicitly shifted whole plants to war contract production of military goods and

20 We have also performed the same sequence of estimations using the growth in manufacturing value added per capita for the periods 1939-1947 and 1939-1954 as the measures of economic activity. Again, the results are very similar to those found for retail sales per capita. 
subsequently reduced the production of consumer goods at those plants. Shortages of key materials contributed to this crowding out. In contrast, the New Deal public works and relief projects were created in a setting where the share of the work force without private sector jobs ranged from 10 to 25 percent. There was plenty of unemployment to soak up by building government public works before private employment might have been affected. In this sense of crowding out, the New Deal AAA programs that took land out of production is more similar to the war spending. In fact, Fishback, Horrace, and Kantor (2005) found no positive effect of the AAA spending on retail sales spending.

Second, the growth rate for retail sales in the war spending study includes years in the aftermath of the war, while the New Deal study does not include post-New Deal years. The war spending involved significant costs of conversion from civilian to war production and then back, which was not an issue for the New Deal spending. Thus, the post-war transition likely would have led to a smaller positive war spending coefficient than for the New Deal.

Third, any expansions in income and consumption from war spending were taxed at a much higher rate than similar expansions during the New Deal. During the war average federal tax rates increased sharply from an average of 7 percent to 22 percent. For the first time the majority of households were paying income taxes, compared with less than 7 percent of households during the 1930s.

We considered a fourth possibility, but we do not believe it explains very much of the difference between the effects of the New Deal and the War spending. It is likely that a significantly higher share of war spending than of public works and relief went to inputs imported from outside the county. Roughly 80 to 90 percent of public works and 
relief project spending during the New Deal was spent on earnings; therefore, the value added from the expenditures as well as the initial expenditures within the county accounted for more than 80 to 90 percent of the amount spent. In the case of the war spending, there was no such requirement. Based on typical patterns in manufacturing, our best estimate suggests that about 40 percent of the War spending could be considered value added that was likely to have initially spent locally. Although we estimated the relationship between retail sales growth and war spending per capita using total war spending, it could be said that what we really wanted to measure was war production value added per capita to focus on the expenditures that we could expect would have remained in the county. It turns that in cross-county analysis in other periods the correlation between manufacturing value added per capita and total revenue for manufacturing per capita is .93 , which is very close to being a constant. Since value added is typically 40 percent of total revenue, assume that the constant is ratio of value added to revenue is .4 , which implies the ratio of total revenue to value added is 2.5 . Econometrically, we have come close to estimating the equivalent of the following simple relationship.

Retail Sales Growth $=\alpha+\gamma(2.5 *$ War Production Value Added per Capita $)$

when we wanted to estimate.

Retail Sales Growth $=\alpha+\beta$ War Production Value Added per Capita. 
Econometrics textbooks show that the coefficient we actually estimated $(\gamma)$, would be

$$
\gamma=0.4 * \beta, \text { which implies } \beta=2.5 * \gamma
$$

Therefore, we should scale up the coefficient estimates that we have produced by 2.5 . However, the estimates of the impact of war spending on retail sales growth are so small, than even after scaling them by 2.5 does not change the finding of a very small effect of war spending on retail sales growth per capita.

\section{The Impact of War Spending on Other Economic Dimensions}

Given the narratives about the effects of World War II spending, the lack of an effect of war spending on retail sales growth will surprise most observers. It is therefore natural to wonder how the economic fabric of the local economies stretched to accommodate such intense spending. For example, we know that real income payments rose while real per capita consumption fell (Higgs, 1990); therefore, it is likely that the war production counties saw a significant increase in savings in the form of government bond purchases, bank deposits, or home ownership. In the following section we examine these savings vehicles and other economic characteristics of the counties that likely were shaped by war spending in the 1940s, including growth in manufacturing annual earnings and labor productivity, changes in the importance of manufacturing, changes in labor force activity by women, the growth in housing values, and population growth.

For most characteristics we analyze the medium term changes between 1939 and the late 1940s, as we did with retail sales. In the case of E-bond purchases and bank deposits, we can also examine information from 1944. Table 8 describes the effect of a one standard deviation increase in war spending per capita on the dependent variable for 
a series of regression specifications, summarized in the lower portion of the table. The second to last row for each variable shows the results from the differenced model that subtracts the 1930s information from the 1940s information without state effects. The bottom specification adds the state effects. The effects based on statistically significant coefficients are marked with a single asterisk for the ten percent level of significance and two asterisks for the five percent level. The complete regression results for each variable of interest across all specifications are available from the authors. The results in Table 8 show that omitted variable bias is likely an issue for the simplest specification with the growth rate as a function of per capita war spending and for the specification that includes lagged levels of the dependent variable and prior growth trends. The addition of other controls generally leads to substantial changes in the size of the coefficients used to calculate the one-standard deviation effects. ${ }^{21}$ When examining the magnitudes of the coefficient we use the coefficients from specification 9, which is the model that uses the differences between the 1940s and 1930s decades and controls to the greatest extent for omitted variable bias. As noted in the prior section, we might want to scale the magnitudes of the coefficients upward by multiplying by 2.5 . As will be seen, the magnitudes for all but E-bond sales in 1944 and the growth rate in population from 1940 through 1950 are so small that the rescaling would make little difference to the qualitative story told by the results.

Savings in the Form of E-Bonds, Bank Deposits, Housing Values and Home Ownership

\footnotetext{
${ }^{21}$ For all of the different variables, we have run specifications where the dependent variable is the level in the final year as a function of the prior level before the war and all of the other correlates. The qualitative results are the same and the magnitudes do not vary much.
} 
Standard descriptions of strong effects of the war spending on prosperity argue that workers faced with rationing often put their increased income into savings during the War. Many saved by buying E-bonds, accumulating bank deposits, and/or buying housing, which was not rationed during the war. The savings could then be used for more consumption after the war. The first step in the narrative can be examined by estimating the impact of war spending on per capita E-bond sales at the issue price and per capita bank deposits (demand and time in state and national banks) in 1944 near the end of the war and again in 1949. In addition, we examine the change in home ownership rates and the growth rate in the median value of homes between 1940 and 1950. All monetary measures are adjusted for inflation using the CPI $(1967=100)$. E-bonds, also known as "war" bonds, were first sold in 1941 and were the dominant form of savings bond sold to small investors during the war. ${ }^{22}$ E-bond sales accounted for roughly 75-80 percent of all savings bond sales each year between 1943 and 1950 (U.S. Treasury, 1950, 558). Since there were no E-bonds sold prior to 1941, the number of E-bond sales in 1944 and in 1949 are the same as the change in E-bond sales over that period. There were A, B, C, and D issues of savings bonds between 1935 and 1940 but we do not have information on sales of those bonds at the county level. The sales of the earlier issues were one-tenth the level of E-bond sales in 1944; therefore, we do not believe that controlling for their prior level will make much difference. We have not been able to obtain county bank deposit information between 1937 and 1943 at the

\footnotetext{
${ }^{22}$ Series $\mathrm{F}$ and $\mathrm{G}$ bonds were also sold to the public but were targeted at larger investors. The $\mathrm{E}$ bonds could be obtained at post offices and a wide range of financial institutions. F and G series bonds could be purchased only at the Federal Reserve Banks and the Treasury Department, usually with the assistance of a commercial bank. (U.S. Treasury Department 1941, 23)
} 
county level; therefore we use information from 1936 as the prior level. Both measures are adjusted for inflation using the CPI $(1967=100)$..

War spending had a positive and statistically significant impact on E-bond purchases and bank deposits in 1944 during the War, but had a slightly negative middle run effect when the analysis is based on the year 1949. Using the fullest OLS specification to eliminate issues with omitted variables, a one-standard deviation increase in war spending per capita over the period 1939 through 1945 raised Ebond sales per capita in 1944 by 0.294 standard deviations and bank deposits by 0.050 standard deviations. The E-bond sales effect is a sizeable one, roughly the same size as the effect on E-bond sales of the level of retail sales per capita in 1939 (not reported). In dollar-fordollar terms an additional dollar per capita of war spending during the war raised E-bond sales by 0.4 cents in 1944 . This may seem small at first, but remember that only about 30 percent of the war spending was paid directly as wages. Assuming the typical worker saved about 5 percent of their income, they normally would have saved 1.5 cents out of the 30 cents of income derived from the dollar of war spending. Thus, the 0.4 cent increase would have accounted for a little less than one third of the rise in a worker's savings. The effect was much smaller for bank deposits.

The results for the 1949 figures suggest that any positive effect on savings had gone away by the end of the decade. The one standard deviation effects of war spending per capita were negative but small, less than 0.04 standard deviations. The middle run effects, like the retail sales effects suggest that counties with more war spending had no higher savings in the middle-run or longer-term. The positive effects on savings during 
the War might suggest that if we had had accurate retail sales measures in 1944 or 1945 that we would have seen some war stimulus to those sales.

Since housing is a major portion of the typical home owner's wealth, housing might also be considered a form of saving. Similar to the small effects found on bond sales and bank deposits, counties with more war spending per capita experienced slightly higher growth rates of housing values between 1940 and 1950 and slighty lower home ownership rates between 1940 and 1950 .

\section{Manufacturing Wages and Share of Workers in Manufacturing}

The war spending was focused heavily on manufacturing; therefore, it is likely that the strongest structural changes arising from the war spending would have come in the form of a shift to the manufacturing sector. We investigate the middle-run changes within manufacturing associated with several measures: the growth rates between 1939 and 1947 in annual manufacturing earnings for production workers in 1967 dollars and in manufacturing value added per worker in 1967 dollars. In addition, we examine two measures of the size of manufacturing's role in the local economy, the change in the share of workers employed in manufacturing between 1940 and 1950 and the growth rate in manufacturing value added per capita between 1939 and 1947. In all specifications, we control for the prior level of the variable and the trend in the prior decade.

The results in Table 8 show that there was very little change in the impact of war spending on annual earnings and labor productivity within manufacturing. The onestandard deviation effects are less than 0.025 in both cases and neither is statistically 
different from zero. The war spending did lead to a statistically significant but very slight increase in the share of workers in manufacturing and in the value added per capita.

\section{Women's employment}

Histories of WWII point to women's participation in the workforce as a key element of the war effort during WWII. Many people had thought World War II led to permanent changes in women's labor force participation. Claudia Goldin (1991), however, examined the issue using retrospective labor histories from 1944 and 1951 surveys collected by Gladys Palmer. The retrospective histories show that only 20 percent of women working in 1950 had entered the work force during World War II and that the rate of entry of women into the workforce was roughly the same during the War as it was from 1946 to 1950 . We examine the issue using an alternative set of data that covers the entire workforce in the United States by estimating the impact of war spending per capita on the change in the percentage of women in the population who were employed and on the change in women's share of the workforce.

The results are similar to Goldin's finding. War spending had at best a small positive impact on women's roles in the workplace by 1950 . Counties with war spending per capita that was one standard deviation larger than the mean, had a female share of the workforce that rose by a relatively small but statistically significant 0.022 standard deviations. Meanwhile, the employment rate for women rose a small and statistically insignificant 0.004 standard deviations.

\section{Population Growth}


Numerous narratives describe World War II as a period of significant internal movement within the United States. A substantial number of people moved from economically stagnant areas to cities experiencing labor shortages due to rapid expansions in war production (U.S. Bureau of Labor Statistics, 1944). The rise in population described during the war carried through the end of the decade, as a substantial number of civilians moved to war production areas during the war and many stayed in the new location rather than incur the costs of a return migration. The effect may have been compounded somewhat when soldiers were demobilized and returned to new locations rather than their original home. Counties with war spending per capita that was higher by one standard deviation experienced population growth that was 0.217 standard deviations higher. This effect was second in size only to the one-standard deviation effect for E-bond sales in 1944.

\section{Conclusions}

Our goal was to measure whether community leaders would have found it beneficial in the long term to compete to obtain military contracts and facilities for their communities during the War. The answer appears to be no, unless the goal was to expand the population base. The sharp rise and fall in World War II military spending contributed to a substantial redistribution of the population between 1940 and 1950 toward the counties where the spending was concentrated during the War. However, the rise in war-time military spending in a county had virtually no longer term effect on per capita measures of economic activity, including per capita retail sales, E-bond sales, bank deposits, manufacturing annual earnings, manufacturing productivity per worker, 
women's share of the workforce, the share of manufacturing in the economy, housing values and home ownership.

Aside from the E-bond sales and bank deposits, we have not estimated the impact of the war spending at the time it was spent. There was a strong effect of war spending on sales of E-bonds per capita during the war and a small positive effect on bank deposits per capita. However, the effect was no longer there by 1949. The pattern for E-bond sales is suggestive that there was an immediate stimulus from the War that was not sustained once the military demobilization occurred.

The question remains as to why the longer-term effect of spending on per capita measures is so small. One possibility is that the true effect of World War II spending was a series of economy-wide macroeconomic shocks to the entire economy at once, including a large-scale shift toward a command economy. The tremendous economic diversity of the various regions of the United States raises some doubts that such a shock would have the same effects everywhere. However, it is possible that the War years pushed the U.S. Economy to the edge of the production possibility frontier on every dimension. Thus farmers and areas that did not receive much in military manufacturing spending and facilities still experienced large-scale increases in demand, so that it did not matter whether a county participated or not in the scramble for military manufacturing contracts in the short or the long term.

There are also reasons to believe that the gains from obtaining war contracts at the local level were offset by similar-sized costs. Nearly all of the military production directly crowded out the production of goods for private consumption and investment. Further, the transition costs from civilian production to military production before the 
War and then the reconversion back to civilian production following the War likely ate into the benefits of war production. Finally, the administration of the War imposed a large tax burden on expansions of income during the war, as income tax rates and the share of the American public paying taxes rose sharply. These taxes imposed a strong fiscal drag that would have diminished the local benefits to individuals in the counties. 


\section{Data Appendix}

\section{War Spending.}

War spending figures come from the County Data Book of 1947 compiled by the Bureau of the Census and available in part 70 from the ICPSR in the datasets compiled and revised by Michael Haines (no date). There were two categories of war spending: supply contracts and facilities projects. Supply contracts represented major war supply contracts awarded between June 1940 and September 1945 by the War Department, the Navy Department, the Maritime Commission, The Treasury Procurement Division, and foreign purchasing missions as reported to the War Production Board. A major war supply contract was a prime contract involving a sum of $\backslash \$ 50,000$ or more. The total value of contracts reflects the net value of contracts with any contract reductions and cancellations having been deducted. Contracts for combat equipment such as aircraft, ships, and ordnance were separately tabulated from other contracts. Supply contracts were assigned to counties if the location of the principle producing plants were located in the county. If it was not possible to assign a contract definitely to any county, then the contract was omitted. Contracts for foodstuffs and food processing were also omitted.

Facilities projects include any undertaking reported to the War Production Board between June 1940 and June 1945 for which a contract or project order was issued in excess of $\backslash \$ 25,000$. Projects financed by the Army, Navy, Maritime Commission, Defense Plant Corporation, Reconstruction Finance Corporation, and British Empire governments are included. The value of each project represents an estimate of the final cost of the project. Facilities spending was further broken down into industrial facilities spending and military facilities spending. Industrial facilities represent plants constructed to produce war materials such as shipyards, munitions factories, and aircraft plants. Military facilities represent cantonments, airports, and other military installations for which direct outlays were made by the armed forces. The value of any facilities which were constructed using private funds was excluded.

For the purposes of this study supply contracts (both combat supplies and other supplies) and facilities spending (both industrial and military facilities) were aggregated to construct total measure of war spending in a county between 1940 and 1945. Spending was adjusted to 1967 dollars to match other monetary measures in the study.

\section{Industrial Mobilization Counts}

Facility allocations under the Industrial Mobilization Plan were found using the "Directory of Facilities, Allocated and Reserved" compiled by the Office of the Assistant Secretary of War's Planning Branch. This document, which was restricted at the time, was published several times during the 1930's. The data for this study are complied from the version released January 1, 1938.

Almost 10,000 facilities are included in this publication. For each facility the following was recorded: location(city and state), the procuring agency it was assigned to, and finally whether it had a special designation. Some facilities were assigned to more than one procuring agency. Procurement agencies included the Navy Department, Army Quartermaster Corps, Army Ordnance Department, Army Air Corps, Army Corps of Engineers, Army Chemical Warfare Service, Army Signal Corps, Army Medical Department, and the Army Coast Artillery Corps. Special mobilization designations include the Steel Mobilization Plan, Machine Tool facility, Optical \& Precision Instruments facility, Aeronautic facility, Army and Navy Munitions Board facility, and Offices of the Assistant Secretary of War facility.

For each city the total number of facilities were counted. In addition the total number of facilities allocated to each procuring agency was tabulated. The number of facilities with each special designation were also calculated. City counts were then aggregated to the county level. The final data shows the number of facilities in each county which were allocated to each procurement agency and designation. 
Information on the correlates in 1940 and 1930 have been compiled by Price Fishback and Shawn Kantor from a wide range of sources. See the data appendices in Fishback, Horrace, and Kantor $(2005,2006)$ and the NBER working papers associated with those papers. See Price Fishback's website at the Department of Economics at the University of Arizona for access to the working papers and the portions of the data that have already been used in publications. Look at the link dataset from published research at http://econ.arizona.edu/faculty/Fishback.aspx. Population in 1948 was calculated via linear interpolation of populations from U.S. Population Census Information in 1940 and 1950 from Haines (ICPSR).

Fishback and Kantor had combined a number of counties and city districts in areas where the New Deal information was reported for the larger district. For this study additional counties were combined in cases where there were significant boundary changes in the 1940s. In Virginia this involved combining the following cities back into their counties: Bedford city into Bedford county, Chesapeake city into Princess Anne, Virginia Beach City into Princess Anne, Colonial Heights into Prince George, Covington City into Allegheny County; Fairfax City into Fairfax County, Falls Church City into Fairfax County, Franklin City into Southhampton County, Lexington City into Rockbridge, Manassas City into Prince William County, Poquosan City into York, Salem City into Roanoke, Waynesboro City into Augusta County, Emporia City into Greensville County, Galax City into Carroll, Norton City into Wise County. In New Mexico, Los Alamos was created in 1949 out of Sandoval and Santa Fe counties, so we combined them into one. In North Dakota Washington County was eliminated and merged into Shannon County.

E-bond sales in 1944 and 1949, population in 1920, 1930, 1940, 1950, shares of women employed and the share of women in the workforce in 1940 and 1950, home ownership rates and housing values in 1920,1930, 1940 and 1950, manufacturing annual earnings and value added per worker in 1919, 1929, 1939 and 1947 were calculated from data provided in computerized form in Haines (no date, ICPSR 2896) from the U.S. Censuses of 1920, 1930, 1940, and 1950 and the County Data Books from 1947 and 1949. 


\section{References:}

Aschauer, David Alan, “Is Public Expenditure Productive?” Journal of Monetary Economics 23 (March 1989), 177-200.

Bailey, Stephen J., and Stephen Connolly, "The Flypaper Effect: Identifying Areas for Further Research," Public Choice 95 (June 1998), 335-61.

Barro, Robert J., and Xavier Sala-i-Martin, Economic Growth, second edition (Cambridge, MA: MIT Press, 2004).

Costa, Jose da Silva, Richard W. Ellson, and Randolph C. Martin, "Public Capital, Regional Output, and Development: Some Empirical Evidence," Journal of Regional Science 27 (Aug. 1987), 419-37.

Diamond, Jared, Guns, Germs, and Steel: The Fates of Human Societies (New York: W. W. Norton, 1997).

Duffy-Deno, Kevin T., and Randall W. Eberts, "Public Infrastructure and Regional Economic Development: A Simultaneous Equations Approach," Journal of Urban Economics 30 (Nov. 1991), 329-43.

Fernald, John G., "Roads to Prosperity? Assessing the Link between Public Capital and Productivity," American Economic Review 89 (June 1999), 619-38.

Fishback, Price V. Fishback, William C. Horrace and Shawn Kantor. 2005. "Did New Deal Grant Programs Stimulate Local Economies? A Study of Federal

Grants and Retail Sales During the Great Depression," Journal of Economic History 63 (March 2005):

Fishback, Price.V., Horrace, William C., and Kantor S. (2006). "Do Federal Programs Affect Internal Migration? The Impact of New Deal Expenditures on Mobility During the Great Depression," Explorations in Economic History 43 (April 2006): 179-222.

Fishback, Price V., Shawn Kantor, and John Joseph Wallis, "Can the Three R's be Rehabilitated? A Comprehensive Analysis, Program by Program, County by County," Explorations in Economic History 40 (July 2003), 278-307.

Gallop, John Luke, Jeffrey D. Sachs, and Andrew D. Mellinger, "Geography and Economic Development," in Boris Pleskovic and Joseph E. Stiglitz, eds., Annual World Bank Conference on Development Economics, 1998 (Washington, DC: World Bank, 1999), 127-78.

Garcia-Mila, Theresa, and Therese J. McGuire, "The Contribution of Publicly Provided Inputs to States' Economies," Regional Science and Urban Economics, 22 (June 1992), 229-41.

Gardner, John, and William Cohen, "Demographic Characteristics of the Population of the United States, 1930-1950: County-Level," ICPSR file 0020, 1992.

Gramlich, Edward M., "Infrastructure Investment: A Review Essay,” Journal of Economic Literature, 32 (Sept. 1994), 1176-96.

, "Intergovernmental Grants: A Review of the Empirical Literature." In The Political Economy of Fiscal Federalism. Edited by Wallace E. Oates. Lexington, Massachusetts: Lexington Books, 1977.

Greene, William H., Econometric Analysis, Fifth Edition (New York: Prentice Hall, 2003). 
Hahn, Jinyong, and Jerry Hausman, "A new specification test for the validity of instrumental variables," Econometrica 70 (Jan. 2002), 163-89.

Haines, Michael. (no date). Historical, Demographic, Economic, and Social Data: The United States, 1790-2000. Computerized Data sets from the Inter-University Consortium for Political and Social Research (ICPSR). ICPSR No. 2896.

Hausman, Jerry, "Specification and Estimation of Simultaneous Equations Models," In Zvi Griliches and Michael Intrilligator, eds, Handbook of Econometrics (Amsterdam: North-Holland, 1983).

Higgs, Robert. 1992. "Wartime Prosperity? A Reassessment of the US Economy in the 1940's," Journal of Economic History 52 (March): 41-60.

Higgs, Robert. 1993. "Private Profit, Public Risk: Institutional Antecedents of the Modern Military Procurement System in the Rearmament Program of 1940-41." Sinews of War: Essays on the Economic History of World War Industrial Mobilization Plan. Edited by Geofrey T. Mills and Hugh Rockoff. Ames, Iowa: Iowa State University Press, pp. 166-198.

Higgs, Robert. 1999. "From Central Planning to Market, The American Transition, 1945-1947." Journal of Economic History 59 (September): 600-23.

Higgs, Robert. 2004. "Wartime Socialization of Investment: A Reassessment of U. S. Capital Formation." Journal of Economic History 64 (June): 500-520.

Higgs, Robert. 2006. Depression, War, and Cold War: Studies in Political Economy. Independent Institute.

Hines, James R. Jr., and Richard H. Thaler, "The Flypaper Effect," Journal of Economic Perspectives 9 (Fall 1995), 217-26.

Hulten, Charles R., and Robert M. Schwab, "Public Capital Formation and the Growth of Regional Manufacturing Industries,” National Tax Journal 44 (Dec. 1991), 12134.

Inter-University Consortium for Political and Social Research, Historical, Demographic, Economic, and Social Data: The United States, 1790-1970, ICPSR Number 0003. The version has corrections by Michael Haines, Department of Economics, Colgate University, Hamilton, NY.

Inter-University Consortium for Political and Social Research, United States Historical Election Returns, 1824-1968, ICPSR Number 0001.

Koistinen, Paul A. C. 2004. Arsenal Of World War II, The Political Economy Of American Warfare. Lawrence, Kansas: University Press of Kansas.

Kuznets, Simon. National Product in Wartime. New York, 1945.

McGregor, Peter, Eric McVittie, J. Kim Swales, and Ya Ping Yin, "The Neoclassical Economic Base Multiplier," Journal of Regional Science 40 (Feb. 2000), 1-31.

Melman, Seymour. 1985. The Permanent War Economy: American Capitalism in Decline. New York: Simon and Schuster.

Merrifield, John, "A Neoclassical Anatomy of the Economic Base Multiplier," Journal of Regional Science 27 (May 1987), 283-94.

Munnell, Alicia, "Infrastructure Investment and Economic Growth," Journal of Economic Perspectives 6 (Fall 1992), 189-98.

Nelson, Donald Marr. 1946. Arsenal Of Democracy, The Story Of American War Production. New York: Harcourt, Brace and Company, 
Nordhaus, William and James Tobin. 1972. "Is Growth Obsolete?” in National Bureau of Economic Research volume on Economic Growth 96: 1-80.

Novick, David, Melvin Anshen, and William Charles Truppner. 1949. Wartime Production Control. New York: Columbia University Press.

Oates, Wallace, Fiscal Federalism (New York: Harcourt Brace Jovanovich, 1973).

Pereira, Alfredo M., and Rafael Flores de Frutos, "Public Capital Accumulation and Private Sector Performance," Journal of Urban Economics 46 (September 1999), 300-22.

Rappaport, Jordan, and Jeffrey D. Sachs, "The United States as a Coastal Nation," Journal of Economic Growth 8 (March 2003), 5-46.

Rhode, Paul, James Snyder, and Koleman Strumpf. 2002. "The Great Arsenal of Democracy": The Political Economy of the County Level Allocation of World War Two Military Spending. Working Paper presented at the NBER Summer Institute.

Schubert, Frank. 1994. Mobilization: the United States Army in World War II. Defense Dept., Army, Center of Military History.

Smith, R. Elberton. 1959. The Army and Economic Mobilization. Washington, D.C. Center of Military History, U.S. Army. Washington, D.C.: Government Printing Office reprinted 1991.

United States Bureau of Budget. 1946. The United States at War: Development and Administration of the War Program by the Federal Government. New York: Da Capo Press, Inc.,

United States Bureau of the Census. (1975). Historical Statistics of the United States: Colonial Times to 1970. Part II. Washington, D.C.: Government Printing Office.

U.S. Bureau of the Census. County Data Book. (Washington, D.C.: Government Printing Office, 1947.

U.S. Bureau of the Census. County and City Data Book. (Washington, D.C.: Government Printing Office, 1949.

U.S. Bureau of the Census, Historical Statistics of the United States: Colonial Times to 1970 (Washington, DC: GPO, 1975).

U.S. Bureau of the Census, "Illiteracy in the United States, October 1947," Current Population

U.S. Congress, Official Congressional Directory, for the $73^{\text {rd }}$ Congress $1^{\text {st }}$ session through $76^{\text {th }}$ Congress (Washington, D.C.: GPO, various years).

U.S. Bureau of the Census. Fifteenth Census of the United States, 1930, Population, Volume VI: Families. Washington, D.C.: Government Printing Office, 1933.

U.S. Bureau of the Census, Sixteenth Census of the United States, 1940: Population, Internal Migration, 1935 to 1940 (Washington, DC: GPO, 1943).

U.S. Bureau of Labor Statistics. "State Variations in War Migration and Post-War Demobilization." Monthly Labor Review (September 1944): 481-485.

U.S. Department of Commerce, Bureau of Foreign and Domestic Commerce, Consumer Market Data Handbook. (Washington, D.C.: GPO, 1936).

U.S. Department of Commerce, Bureau of Foreign and Domestic Commerce, Consumer Market Data Handbook. (Washington, D.C.: GPO, 1939).

U.S. Department of Commerce, Bureau of Foreign and Domestic Commerce, General Consumer Market Statistics, Supplement 1 to the Market Data Handbook of the 
United States. (Washington, D.C.: GPO, 1932).

U.S. Office of Government Reports, Statistical Section, Report No. 9, Volume 1, "Direct and Cooperative Loans and Expenditures of the Federal Government for Fiscal Years 1933 through 1939." Mimeo, 1940.

U.S. Office of Government Reports, Statistical Section, Report No. 10, Volume 1, "County Reports of Estimated Federal Expenditures March 4 1933-June 30, 1939," Mimeo, 1940.

United States Joint Army and Navy Munitions Board. 1933. Industrial Mobilization Plan. Washington DC: United States Government Printing Office. 1933

United States Joint Army and Navy Munitions Board. 1938. Industrial Mobilization Plan. Revision Of 1938. Washington DC: United States Government Printing Office.

United States Joint Army and Navy Munitions Board. 1939. Industrial Mobilization Plan. Revision Of 1939. A Study Of Methods For The Effective And Equitable Utilization Of The Industrial Resouces Of The United States In Time Of War., Washington DC: United States Government Printing Office.

Vias, Alexander and Gordon Mulligan. 1997. "Disaggregate Economic Base Multipliers in Small Communities." Environment and Planning 29 (June): 955-74. 
Table 1

Predicted Change in Retail Sales from an Additional Dollar of War Spending

$$
\text { Under Various Assumptions }
$$

$\begin{array}{cccccc}\begin{array}{c}\text { Share } \\ \text { population } \\ \text { spends } \\ \text { externally }\end{array} & \begin{array}{c}\text { Base } \\ \text { Multiplier }\end{array} & \begin{array}{c}\text { Crowding } \\ \text { Out/ } \\ \text { Productivity }\end{array} & \begin{array}{c}\text { Share of } \\ \text { War } \\ \text { plant } \\ \text { inputs } \\ \text { imported }\end{array} & \begin{array}{c}\text { Income } \\ \text { Multiplier }\end{array} & \begin{array}{c}\text { Change } \\ \text { in Retail } \\ \text { Sales } \\ \text { from } \$ 1 \\ \text { of New } \\ \text { Deal } \\ \text { spending } \\ \text { M }\end{array} \\ M & \Pi & \Pi & m_{w} & M & \begin{array}{c}r \mu \\ \text { M }\end{array}\end{array}$

\section{EXTRA INCOME IS SPENT 75 \% LOCALLY, $25 \%$ EXTERNALLY}

1 Baseline

0.25

1.33

$-0.5$

0.3

0.13

20.2 rise in

0.25

1.33

$-0.7$

0.3

0.25

$-0.01$ crowding out

3 No crowding

0.25

1.33

0

0.3

0.92

0.49 out

4 Baseline

0.25

1.33

$-0.5$

0.5

$-0.01$

$-0.01$

with 0.2 rise

in war plant

share of

inputs

imported

\section{EXTRA INCOME IS SPENT 50\% LOCALLY, 50 \% EXTERNALLY}

$\begin{array}{llllllll}5 & \text { Baseline } & 0.5 & 0.80 & -0.5 & 0.3 & 0.15 & 0.08 \\ 6 & \begin{array}{l}\text { 0.2 rise in } \\ \text { crowding }\end{array} & 0.5 & 0.80 & -0.7 & 0.3 & -0.01 & 0.00 \\ \text { out } & & & & & & \\ 7 & \begin{array}{l}\text { No crowding } \\ \text { out }\end{array} & 0.5 & 0.80 & 0 & 0.3 & 0.55 & 0.29 \\ 8 & \begin{array}{l}\text { Baseline } \\ \text { Bat }\end{array} & 0.5 & 0.80 & -0.5 & 0.5 & -0.01 & 0.00\end{array}$

with 0.2 rise

in war plant

share of

inputs

imported

Assumptions:

$r$ the ratio of retail sales to income is assumed 0.53 .

$t_{f}$ the fed tax rate is 0.2 .

$\theta$ the flypaper/crowding out effect on state and local spending is 0.1 .

$\delta$ the ratio of state and local taxes to state and local spending is 0.9 . 
Table 2

Change in the Estimated Impact of War Spending on Retail Sales Growth, 19391948 As Correlates Are Added in a Cumulative Fashion

\begin{tabular}{|c|c|c|c|c|c|}
\hline Specification & Variables in Specification & $\begin{array}{c}\text { War } \\
\text { Spending } \\
\text { Coefficient }\end{array}$ & P-Value & $\begin{array}{l}\text { OSD } \\
\text { Change }\end{array}$ & $\begin{array}{l}\text { Dollar } \\
\text { Change }\end{array}$ \\
\hline 1 & War & $-8.54 \mathrm{E}-06$ & 0.000 & -0.190 & $-\$ 0.0046$ \\
\hline 2 & (1) + Retail Sales 1939 & $-5.09 \mathrm{E}-06$ & 0.000 & -0.113 & $-\$ 0.0027$ \\
\hline 3 & (2) + Economic Correlates & $-2.91 E-06$ & 0.000 & -0.065 & $-\$ 0.0016$ \\
\hline 4 & (3) + Demographic Correlates & $-1.11 \mathrm{E}-06$ & 0.019 & -0.025 & $-\$ 0.0006$ \\
\hline 5 & (4) + Geographic Correlates & $-1.27 \mathrm{E}-06$ & 0.012 & -0.028 & $-\$ 0.0007$ \\
\hline 6 & $(5)+$ Climatic Correlates & $-1.04 \mathrm{E}-06$ & 0.026 & -0.023 & $-\$ 0.0006$ \\
\hline 7 & $(6)+$ State Dummies & $-9.53 E-07$ & 0.106 & -0.021 & $-\$ 0.0005$ \\
\hline
\end{tabular}

Notes. Results for specification 7 are reported for all variables except state dummies in Table 4.

Table 3

\section{Exploratory Specifications}

\begin{tabular}{|c|c|c|c|c|c|c|}
\hline Specification & Description & $\begin{array}{c}\text { War } \\
\text { Spending } \\
\text { Coefficient }\end{array}$ & P-Value & $\begin{array}{l}\text { OSD } \\
\text { Change }\end{array}$ & $\begin{array}{l}\text { Dollar } \\
\text { Change }\end{array}$ & $\mathrm{N}$ \\
\hline 8 & No Spending Above 95 percentile & $-5.88 \mathrm{E}-06$ & 0.048 & -0.032 & $-\$ 0.0031$ & 2885 \\
\hline 9 & $\begin{array}{l}\text { Positive Spending Only } \\
\text { Positive Snendino } 5 \text { th }<\text { war }<\end{array}$ & $-7.41 \mathrm{E}-07$ & 0.190 & -0.026 & $-\$ 0.0004$ & 1763 \\
\hline 10 & $95^{\text {th }}$ & $-2.10 \mathrm{E}-06$ & 0.264 & -0.023 & $-\$ 0.0011$ & 1589 \\
\hline 11 & Common Support & $-2.08 \mathrm{E}-06$ & 0.000 & -0.050 & $-\$ 0.0011$ & 1252 \\
\hline 12 & Zero-One Treatment Effect & $-1.59 \mathrm{E}-02$ & 0.029 & -0.036 & $-\$ 8.4739$ & 3036 \\
\hline 13 & Ag Production & $-6.69 \mathrm{E}-07$ & 0.381 & -0.015 & $-\$ 0.0004$ & 3059 \\
\hline
\end{tabular}

Notes. Uses specification 7 from Table 2. 


\section{Table 4: Coefficients and p-values from OLS and 2SLS Regressions}

Variables

Variable of Interest:

Annual War Spending Per Capita

Instrumental Variables:

Army Quartermaster Allocations

Navy Allocations

Army Engineers Allocations

Tool Plan Allocations

OASW Allocations

Areo Allocations

Steel Plan Allocations

Exogenous Variables

Log retail sales per capita

$\%$ dwellings $\mathrm{w} /$ radio, 1940

$\%$ retail sales growth, 1930-40

$\%$ employment in manufacturing, 1940

$\%$ of population female, 1940

$\%$ of population black, 1940

$\%$ of population urban, 1940

$\%$ of population foreign born, 1940

$\%$ of population illiterate, 1940

$\%$ of population in age categories, 1940

$10-19$
$20-29$
$30-34$
$35-44$
$45-54$
$55-64$
$65-u p$

\# rivers in county flowing through 11-20 counties \# rivers in county flowing through $21-50$ counties

\# rivers in county flowing through $>50$ counties

Elevation range

Max elevation

Number of bays

Number of lakes

Number of beaches

Number of swamps

Atlantic coast county

Pacific coast county

Gulf coast county

Great Lakes county

Dustbowl

$\%$ of population farming

Average monthly temperature, 1940-50

Average monthly precipitation, 1940-50

Months of excess or severe drought, 1940-50

Months of excess or severe wetness, 1940-50

$\%$ of population farming $\mathrm{X}$ avg. temperature

$\%$ of population farming $X$ avg. precipitation

$\%$ of population farming $X$ months of drought

$\%$ of population farming $X$ months of wetness

Constant

State fixed effects

$\mathrm{R}^{2}$

$\mathrm{N}$

\begin{tabular}{clll}
\multicolumn{2}{c}{ OLS } & & \multicolumn{2}{c}{ First stage } \\
\cline { 1 - 1 } Coeff & P-value & & Coeff $\quad \begin{array}{l}\text { P- } \\
\text { value }\end{array}$ \\
$-9.53 \mathrm{E}-07$ & 0.106
\end{tabular}

SLS

Second stage
Coeff $\quad \begin{aligned} & \text { P- } \\ & \text { value }\end{aligned}$

$1.20 \mathrm{E}-06 \quad 0.630$

$\begin{array}{cc}-65.2 & 0.001 \\ 381.1 & 0.030 \\ 392.9 & 0.005 \\ 425.7 & 0.001 \\ - & \\ 1482.5 & 0.041 \\ 1308.8 & 0.001 \\ -590.0 & 0.013\end{array}$

$-0.041 \quad 0.066$

$-3.36 \mathrm{E}-04 \quad 0.674$

$-0.001 \quad 0.000$

0.001

0.006

$-0.001$

$-0.001$

0.002

$-0.001$

0.029

$-0.011$

0.031

$-0.007$

0.010

0.016

0.001

0.009

0.008

0.023

3.71E-06

$-8.28 \mathrm{E}-06$

$-1.22 \mathrm{E}-04$

$-1.96 \mathrm{E}-05$

$-0.002$

4.18E-04

0.032

0.006

0.015

0.002

0.066

0.007

0.001

0.007

0.002

0.002

$-6.89 \mathrm{E}-05$

$-3.52 \mathrm{E}-04$

$-4.40 \mathrm{E}-05$

1.24E-05

$-0.381$

Included

0.54

3036

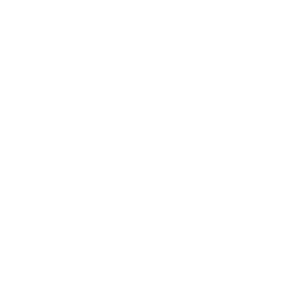

-3.95E-04 0.617

$-0.001 \quad 0.000$

$0.001 \quad 0.493$

0.006

$-0.001$

$-0.001$

0.002

$-0.001$

0.029

$-0.012$

0.032

$-0.007$

0.009

0.017

0.001

0.008

0.007

0.022

0.000

$-7.94 \mathrm{E}-06$

$-1.39 \mathrm{E}-04$

$-1.79 \mathrm{E}-05$

$-0.002$

4.51E-04

0.030

0.003

0.013

0.003

0.064

0.007

0.001

0.007

0.002

0.002

$-6.75 \mathrm{E}-05$

$-3.70 \mathrm{E}-04$

$-4.41 \mathrm{E}-05$

$1.26 \mathrm{E}-05$

$-0.406$

Included

0.54

0.232
$-0.037 \quad 0.094$

$9441.5 \quad 0.211$

3036

3036
Summary Stats

Mean Dev Min Max

132

$\begin{array}{llll}2.0 & 15.96 & 0.0 & 504 \\ 0.3 & 2.93 & 0.0 & 139 \\ 0.2 & 1.76 & 0.0 & 62 \\ 0.1 & 0.88 & 0.0 & 28 \\ 0.0 & 0.55 & 0.0 & 25 \\ 0.0 & 0.32 & 0.0 & 14 \\ 0.1 & 0.82 & 0.0 & 29\end{array}$

$\begin{array}{llll}0.1 & 0.82 & 0.0 & 29\end{array}$

$\begin{array}{llll}6.1 & 0.58 & 3.2 & 8\end{array}$

$\begin{array}{llll}69.3 & 19.90 & 13.2 & 98\end{array}$

$\begin{array}{llcc}97.6 & 60.13 & - & \end{array}$

$\begin{array}{llll}4.0 & 4.27 & 0.0 & 28\end{array}$

$\begin{array}{llll}48.6 & 1.98 & 19.6 & 53\end{array}$

$\begin{array}{llll}10.7 & 17.84 & 0.0 & 86\end{array}$

$\begin{array}{llll}22.8 & 24.51 & 0.0 & 100\end{array}$

$\begin{array}{llll}3.7 & 4.62 & 0.0 & 29\end{array}$

$\begin{array}{llll}5.7 & 5.02 & 0.3 & 41\end{array}$

$\begin{array}{llll}19.9 & 2.52 & 8.9 & 27\end{array}$

$\begin{array}{llll}16.5 & 1.73 & 12.2 & 47\end{array}$

$\begin{array}{llll}7.1 & 0.88 & 3.9 & 13\end{array}$

$\begin{array}{llll}12.2 & 1.45 & 8.4 & 18\end{array}$

$\begin{array}{llll}10.6 & 1.76 & 4.3 & 17\end{array}$

$\begin{array}{llll}7.8 & 1.77 & 1.4 & 14\end{array}$

$\begin{array}{llll}7.1 & 2.29 & 0.0 & 15\end{array}$

$\begin{array}{llll}0.24 & 0.45 & 0.0 & 2\end{array}$

$\begin{array}{lll}0.14 & 0.37 & 0.0\end{array}$

$\begin{array}{lll}0.09 & 0.29 & 0.0\end{array}$

$1517 \quad 2359 \quad 11.0$

$2397 \quad 2959 \quad 11.0$

$\begin{array}{lll}3.0 & 13.95 & 0.0\end{array}$

$\begin{array}{lll}21.0 & 55.31 & 0.0\end{array}$

$0.50 \quad 3.15 \quad 0.0$

$\begin{array}{lll}2.4 & 8.07 & 0.0\end{array}$

$\begin{array}{lll}0.043 & 0.20 & 0.0\end{array}$

$\begin{array}{lll}0.013 & 0.11 & 0.0\end{array}$

$\begin{array}{lll}0.018 & 0.13 \quad 0.0\end{array}$

$\begin{array}{lll}0.027 & 0.16 & 0.0\end{array}$

$\begin{array}{lll}0.016 & 0.13 & 0.0\end{array}$

$\begin{array}{lll}46.2 & 21.62 & 0.0\end{array}$

$\begin{array}{lll}54.4 & 8.15 \quad 37.0\end{array}$

$\begin{array}{lll}3.2 & 1.12 & 0.4\end{array}$

$\begin{array}{lll}9.0 & 8.78 & 0.0\end{array}$

$\begin{array}{lll}12.2 & 12.80 & 0.0\end{array}$

$\begin{array}{lll}2546 & 1329 & 0.0\end{array}$

$149.9 \quad 98.11 \quad 0.0$

$\begin{array}{lll}429.5 & 521.9 & 0.0\end{array}$

$\begin{array}{lll}572.3 & 693.2 & 0.0\end{array}$ 


\section{Table 5: OLS Estimates Differenced Between 1940s and 1930s}

Variables

Variable of Interest:

Annual War Spending Per Capita

Exogenous Variables

$\Delta$ Public Relief Spending 1930's

$\Delta$ Log retail sales per capita

$\Delta \%$ dwellings $\mathrm{w} /$ radio, 1940

$\Delta \%$ population growth, $1930-40$

$\Delta \%$ employment in manufacturing, 1940

$\Delta \%$ of population female, 1940

$\Delta \%$ of population black, 1940

$\Delta \%$ of population urban, 1940

$\Delta \%$ of population foreign born, 1940

$\Delta \%$ of population illiterate, 1940

$\Delta \%$ of population in age categories, 1940$$
\text { 20-29 }
$$

30-34

$35-44$

$45-54$

$55-64$

65-up

$\Delta \%$ of population farming

$\Delta$ Average monthly temperature, $1940-50$

$\Delta$ Average monthly precipitation, $1940-50$

$\Delta$ Months of excess or severe drought, 1940-50

$\Delta$ Months of excess or severe wetness, 1940-50

$\Delta \%$ of population farming $\mathrm{X}$ avg. temperature

$\Delta \%$ of population farming $\mathrm{X}$ avg. precipitation

$\Delta \%$ of population farming $\mathrm{X}$ months of drought

$\Delta \%$ of population farming $\mathrm{X}$ months of wetness

$\Delta \%$ value of crops from cotton

$\Delta \%$ value of crops from corn

$\Delta \%$ value of crops from wheat

$\Delta \%$ value of crops from tobacco

Constant

State fixed effects

$\mathrm{R}^{2}$

$\mathrm{N}$

\begin{tabular}{ccc} 
OLS \\
\hline Coeff & P-value OSD
\end{tabular}

$\begin{array}{cccc}-2.53 \mathrm{E}-06 & 0.001 & -0.031 & -0.0013 \\ & & & \\ 9.77 \mathrm{E}-05 & 0.403 & 0.012 & \end{array}$

$\begin{array}{lll}-1.269 & 0.000 & -0.794\end{array}$

$-1.53 \mathrm{E}-04 \quad 0.786 \quad-0.003$

$-2.17 \mathrm{E}-05 \quad 0.280 \quad-0.013$

$\begin{array}{lll}0.009 & 0.000 & 0.042\end{array}$

$\begin{array}{lll}-0.006 & 0.401 & -0.014\end{array}$

$\begin{array}{lll}-0.004 & 0.104 & -0.018\end{array}$

$\begin{array}{lll}0.000 & 0.643 & 0.004\end{array}$

$\begin{array}{lll}0.003 & 0.229 & 0.015\end{array}$

$\begin{array}{lll}0.003 & 0.102 & 0.020\end{array}$

$\begin{array}{lll}0.006 & 0.235 & 0.020\end{array}$

$\begin{array}{lll}0.003 & 0.639 & 0.010\end{array}$

$\begin{array}{lll}0.003 & 0.760 & 0.006\end{array}$

$\begin{array}{lll}-0.005 & 0.354 & -0.015\end{array}$

$\begin{array}{lll}0.005 & 0.319 & 0.013\end{array}$

$\begin{array}{lll}0.015 & 0.011 & 0.036\end{array}$

$\begin{array}{lll}0.016 & 0.026 & 0.032\end{array}$

$\begin{array}{lll}0.018 & 0.000 & 0.250\end{array}$

$\begin{array}{lll}0.008 & 0.471 & 0.008\end{array}$

$\begin{array}{lll}-0.116 & 0.000 & -0.069\end{array}$

$\begin{array}{lll}0.003 & 0.000 & 0.153\end{array}$

$\begin{array}{lll}-0.001 & 0.534 & -0.018\end{array}$

$\begin{array}{lll}-4.54 \mathrm{E}-04 & 0.000 & -0.368\end{array}$

$\begin{array}{lll}0.002 & 0.000 & 0.110\end{array}$

$\begin{array}{lll}-7.14 \mathrm{E}-05 & 0.000 & -0.181\end{array}$

$\begin{array}{lll}5.27 \mathrm{E}-05 & 0.001 & 0.093\end{array}$

$\begin{array}{lll}-2.42 \mathrm{E}-04 & 0.695 & -0.006\end{array}$

$\begin{array}{lll}-0.001 & 0.010 & -0.030\end{array}$

$\begin{array}{lll}-0.002 & 0.008 & -0.025\end{array}$

$\begin{array}{lll}-3.82 \mathrm{E}-04 & 0.723 & -0.003\end{array}$

$\begin{array}{lll}0.406 & 0.000 & 0.000\end{array}$

Included

0.84

3032 
Table 6

Change in the Estimated Impact of War Spending on Retail Sales Growth, 19391954 As Correlates Are Added in a Cumulative Fashion and Under Different

\begin{tabular}{|c|c|c|c|c|c|c|}
\hline Specification & Variables in Specification & $\begin{array}{c}\text { War } \\
\text { Spending } \\
\text { Coefficient }\end{array}$ & P-Value & $\begin{array}{l}\text { OSD } \\
\text { Change }\end{array}$ & $\begin{array}{l}\text { Dollar } \\
\text { Change }\end{array}$ & \\
\hline 1 & War & $-1.04 \mathrm{E}-05$ & 0.000 & -0.178 & $-\$ 0.0055$ & \\
\hline 2 & (1) + Retail Sales 1939 & $-4.27 \mathrm{E}-06$ & 0.000 & -0.073 & $-\$ 0.0023$ & \\
\hline 3 & $(2)+$ Economic Correlates & $-2.29 \mathrm{E}-06$ & 0.000 & -0.039 & $-\$ 0.0012$ & \\
\hline 4 & (3) + Demographic Correlates & $-8.67 \mathrm{E}-07$ & 0.148 & -0.015 & $-\$ 0.0005$ & \\
\hline 5 & (4) + Geographic Correlates & $-1.14 \mathrm{E}-06$ & 0.077 & -0.020 & $-\$ 0.0006$ & \\
\hline 6 & $(5)+$ Climatic Correlates & $-9.20 \mathrm{E}-07$ & 0.178 & -0.016 & $-\$ 0.0005$ & \\
\hline 7 & $(6)+$ State Dummies & $-7.65 \mathrm{E}-07$ & 0.382 & -0.013 & $-\$ 0.0004$ & \\
\hline Specification & Alternative Estimations & $\begin{array}{c}\text { War } \\
\text { Spending } \\
\text { Coefficient }\end{array}$ & P-Value & $\begin{array}{l}\text { OSD } \\
\text { Change }\end{array}$ & $\begin{array}{l}\text { Dollar } \\
\text { Change }\end{array}$ & $\mathrm{N}$ \\
\hline 8 & No Spending Above 95 percentile & $-3.33 \mathrm{E}-06$ & 0.400 & -0.014 & $-\$ 0.0018$ & 2881 \\
\hline 9 & Positive Spending Only & $-7.43 \mathrm{E}-07$ & 0.368 & -0.019 & $-\$ 0.0004$ & 1763 \\
\hline 10 & Positive Spending, 5 th $<$ war $<95$ th & $2.18 \mathrm{E}-06$ & 0.376 & 0.017 & $\$ 0.0012$ & 1589 \\
\hline 11 & Common Support & $-2.51 \mathrm{E}-06$ & 0.001 & -0.045 & $-\$ 0.0013$ & 1252 \\
\hline 12 & 0-1 Treatment Effect & $-2.35 \mathrm{E}-02$ & 0.015 & -0.041 & $-\$ 12.500$ & 3032 \\
\hline 13 & Ag Production & $-6.98 \mathrm{E}-07$ & 0.515 & -0.012 & $-\$ 0.0004$ & 3031 \\
\hline 14 & $2 \mathrm{SLS}$ & $4.98 \mathrm{E}-06$ & 0.129 & 0.086 & $\$ 0.0027$ & 3032 \\
\hline 15 & Difference 1939-54 minus 1929-39 & $-3.74 \mathrm{E}-06$ & 0.001 & -0.043 & $-\$ 0.0020$ & 3028 \\
\hline
\end{tabular}


Table 7

Change in the Estimated Impact of War Spending on Retail Sales Growth, 19391958 As Correlates Are Added in a Cumulative Fashion and Under Different Estimations

\begin{tabular}{|c|c|c|c|c|c|c|}
\hline Specification & Variables in Specification & $\begin{array}{c}\text { War Spending } \\
\text { Coefficient }\end{array}$ & P-Value & $\begin{array}{l}\text { OSD } \\
\text { Change }\end{array}$ & $\begin{array}{l}\text { Dollar } \\
\text { Change }\end{array}$ & \\
\hline 1 & War & $-1.25 \mathrm{E}-05$ & 0.000 & -0.197 & $-\$ 0.0067$ & \\
\hline 2 & (1) + Retail Sales 1939 & $-4.87 \mathrm{E}-06$ & 0.000 & -0.077 & $-\$ 0.0026$ & \\
\hline 3 & (2) + Economic Correlates & $-2.57 \mathrm{E}-06$ & 0.000 & -0.041 & $-\$ 0.0014$ & \\
\hline 4 & (3) + Demographic Correlates & $-1.05 \mathrm{E}-06$ & 0.051 & 0.017 & $-\$ 0.0006$ & \\
\hline 5 & (4) + Geographic Correlates & $-1.31 \mathrm{E}-06$ & 0.017 & -0.021 & $-\$ 0.0007$ & \\
\hline 6 & $(5)+$ Climatic Correlates & $-1.04 \mathrm{E}-06$ & 0.080 & -0.016 & $-\$ 0.0006$ & \\
\hline 7 & $(6)+$ State Dummies & $-5.21 \mathrm{E}-07$ & 0.468 & -0.008 & $-\$ 0.0003$ & \\
\hline Specification & Alternative Estimations & $\begin{array}{c}\text { War Spending } \\
\text { Coefficient }\end{array}$ & P-Value & $\begin{array}{c}\text { OSD } \\
\text { Change }\end{array}$ & $\begin{array}{l}\text { Dollar } \\
\text { Change }\end{array}$ & $\mathrm{N}$ \\
\hline 8 & No Spending Above 95 percentile & $-5.86 \mathrm{E}-06$ & 0.144 & -0.023 & $-\$ 0.0031$ & 2882 \\
\hline 9 & Positive Spending Only & $-9.70 \mathrm{E}-07$ & 0.169 & -0.022 & $-\$ 0.0005$ & 1763 \\
\hline 10 & Positive Spending, 5 th $<$ war $<95$ th & $-9.03 E-07$ & 0.695 & -0.006 & $-\$ 0.0005$ & 1589 \\
\hline 11 & Common Support & $-2.25 \mathrm{E}-06$ & 0.001 & -0.036 & $-\$ 0.0012$ & 1252 \\
\hline 12 & 0-1 Treatment Effect & $-1.56 \mathrm{E}-02$ & 0.104 & -0.025 & $-\$ 8.3076$ & 3033 \\
\hline 13 & Ag Production & $-4.56 \mathrm{E}-07$ & 0.589 & -0.007 & $-\$ 0.0002$ & 3032 \\
\hline 14 & 2SLS & 4.86E-06 & 0.097 & 0.077 & $\$ 0.0026$ & 3033 \\
\hline 15 & Difference $1939-58$ minus $1929-39$ & $-4.27 \mathrm{E}-06$ & 0.002 & -0.046 & $-\$ 0.0460$ & 3029 \\
\hline
\end{tabular}


Table 8:

Change in Number of Standard Deviations in Growth Rate of Variables Associated with a One Standard Deviation Increase in War Spending Per Capita

\begin{tabular}{|c|c|c|c|c|c|c|}
\hline & $\begin{array}{c}\text { Ebonds } \\
(1940-44) \\
\end{array}$ & $\begin{array}{c}\text { Ebonds } \\
(1940-49)\end{array}$ & $\begin{array}{c}\text { Bank } \\
\text { Deposits } \\
(1936-44) \\
\end{array}$ & $\begin{array}{c}\text { Bank } \\
\text { Deposits } \\
(1936-49) \\
\end{array}$ & $\begin{array}{c}\text { Manufacturing } \\
\text { Wages (1939- } \\
47) \\
\end{array}$ & $\begin{array}{c}\text { Value } \\
\text { Added Per } \\
\text { Worker } \\
\text { (1939-47) } \\
\end{array}$ \\
\hline Spec (1) & $0.359 * *$ & 0.024 & $-0.060 * *$ & $-0.160 * *$ & $-0.058 * *$ & -0.017 \\
\hline Spec (2) & --- & --- & $0.050 * *$ & $-0.058 * *$ & $0.066 * *$ & $0.062 * *$ \\
\hline Spec (3) & $0.252 * *$ & $-0.051 * *$ & 0.000 & $-0.088 * *$ & $0.034 * *$ & 0.014 \\
\hline Spec (4) & $0.253 * *$ & $-0.046 * *$ & 0.003 & $-0.082 * *$ & $0.035 * *$ & 0.017 \\
\hline Spec (5) & $0.270 * *$ & $-0.031 * *$ & 0.016 & $-0.067 * *$ & $0.032 * *$ & 0.019 \\
\hline Spec (6) & $0.289 * *$ & -0.001 & $0.043 * *$ & $-0.040 * *$ & 0.021 & 0.016 \\
\hline Spec (7) & $0.294 * *$ & 0.003 & $0.050 * *$ & $-0.036 * *$ & 0.021 & 0.014 \\
\hline Spec (8) & $0.325 * *$ & $0.011^{*}$ & 0.016 & $-0.040 * *$ & 0.008 & 0.012 \\
\hline Spec (9) & $0.305^{* *}$ & 0.006 & $0.017^{* *}$ & $-0.038 * *$ & 0.001 & 0.007 \\
\hline
\end{tabular}

\begin{tabular}{lccccccc}
\hline & $\begin{array}{c}\text { Share of } \\
\text { Workforce } \\
\text { Female } \\
(1940-50)\end{array}$ & $\begin{array}{c}\text { Share of } \\
\text { Women } \\
\text { Employed } \\
(1940-50)\end{array}$ & $\begin{array}{c}\text { Share of } \\
\text { Workers } \\
\text { in Manu. } \\
(1939-47)\end{array}$ & $\begin{array}{c}\text { Value } \\
\text { Added Per } \\
\text { Capita } \\
(1939-47)\end{array}$ & $\begin{array}{c}\text { Housing Value } \\
\text { Growth }(1940-\end{array}$ & $\begin{array}{c}\text { Housing } \\
\text { Ownership } \\
\text { Rate } \\
(1940-50)\end{array}$ & $\begin{array}{c}\text { Population } \\
\text { Growth } \\
(1940-48)\end{array}$ \\
\hline \hline Spec (1) & 0.022 & 0.012 & $0.147^{* *}$ & $-0.047^{* *}$ & $-0.074^{* *}$ & $-0.099^{* *}$ & $0.347^{* *}$ \\
Spec (2) & $0.103^{* *}$ & $0.074^{* *}$ & $0.086^{* *}$ & 0.009 & $0.055^{* *}$ & $-0.101^{* *}$ & $0.313^{* *}$ \\
Spec (3) & $0.032^{* *}$ & 0.009 & $0.083^{* *}$ & $0.039^{* *}$ & 0.015 & $-0.044^{* *}$ & $0.222^{* *}$ \\
Spec (4) & $0.033^{* *}$ & 0.016 & $0.089^{* *}$ & $0.041^{* *}$ & 0.014 & $-0.044^{* *}$ & $0.206^{* *}$ \\
Spec (5) & $0.030^{* *}$ & 0.020 & $0.089^{* *}$ & $0.041^{* *}$ & $0.023^{* *}$ & $-0.040^{* *}$ & $0.206^{* *}$ \\
Spec (6) & $0.033^{* *}$ & 0.012 & $0.063^{* *}$ & $0.036^{* *}$ & $0.031^{* *}$ & $-0.051^{* *}$ & $0.208^{* *}$ \\
Spec (7) & $0.026^{*}$ & 0.007 & $0.061^{*}$ & $0.035^{* *}$ & $0.035^{* *}$ & -0.056 & $0.217^{* *}$ \\
Spec (8) & $0.026^{* *}$ & 0.007 & $0.055^{* *}$ & 0.011 & 0.000 & $-0.042^{* *}$ & $0.234^{* *}$ \\
Spec (9) & $0.022^{*}$ & 0.004 & $0.059^{* *}$ & 0.012 & 0.001 & $-0.029 *$ & $0.207^{* *}$ \\
\hline
\end{tabular}

$* *=$ Significant at $5 \%$

$*$ Significant at $10 \%$

Specification one through seven build cumulatively. The first specification includes only war spending per capita. Specification two add prior levels and trends of the dependent variable. Specification three adds demographic characteristics as of 1940. Specification four adds Geographic features of the counties. Specification five adds climate changes during the 1940s. Specification six adds economic factors. Specification 7 adds state fixed effects. Specification 8 is the differencing specification between the 1940s and the 1930s without state fixed effects. Specification 9 is the differencing specification including state fixed effects. 
We also have run specifications where we made adjustments to the samples like the ones we made in specifications 8 through 13 in Table 3 . The results suggest that there would be no qualitative change in our final conclusions using the more restricted samples. 
Figure 1: Total War Spending 1940-45

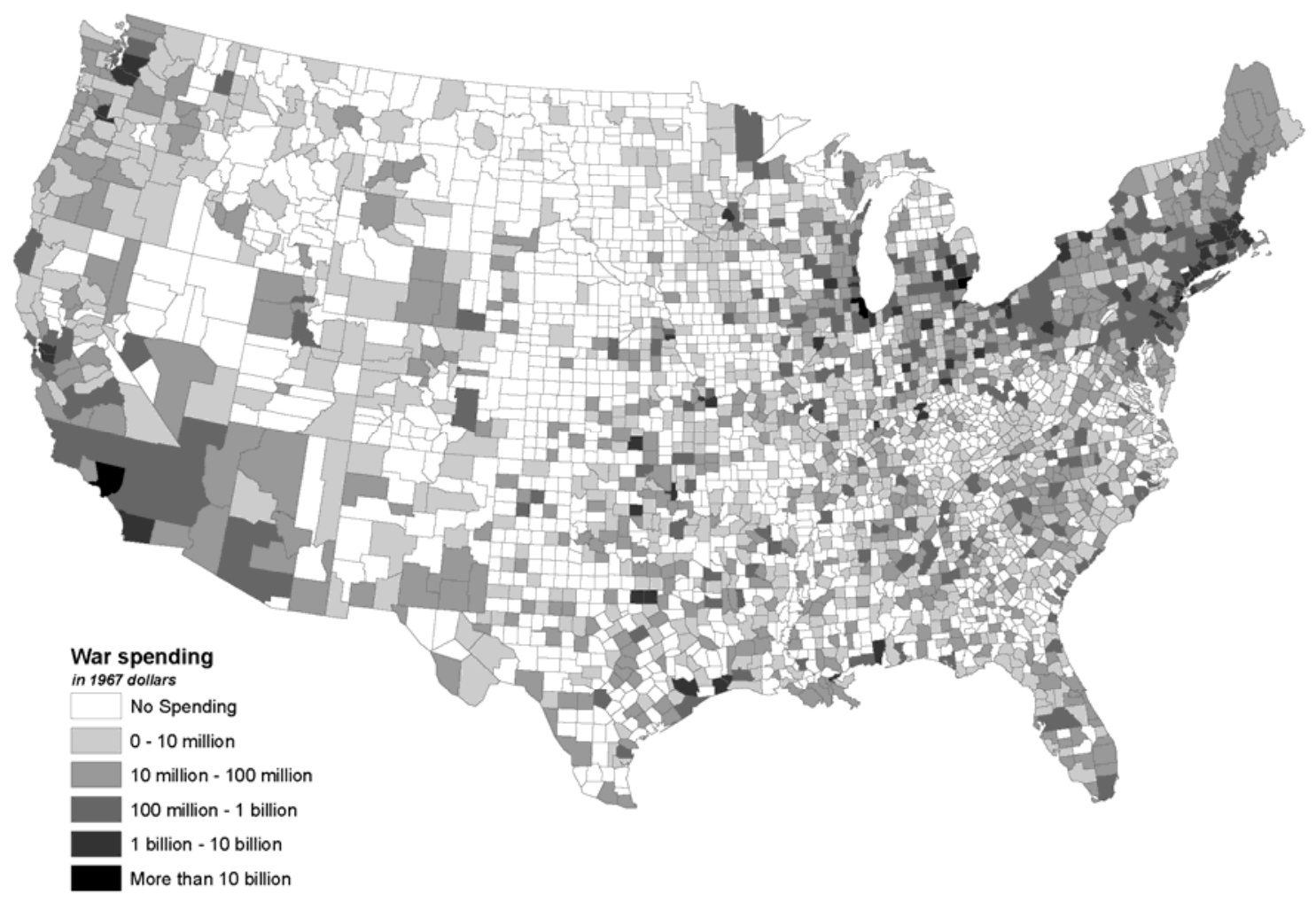


Figure 2: Total War Spending Per Capita 1940-45

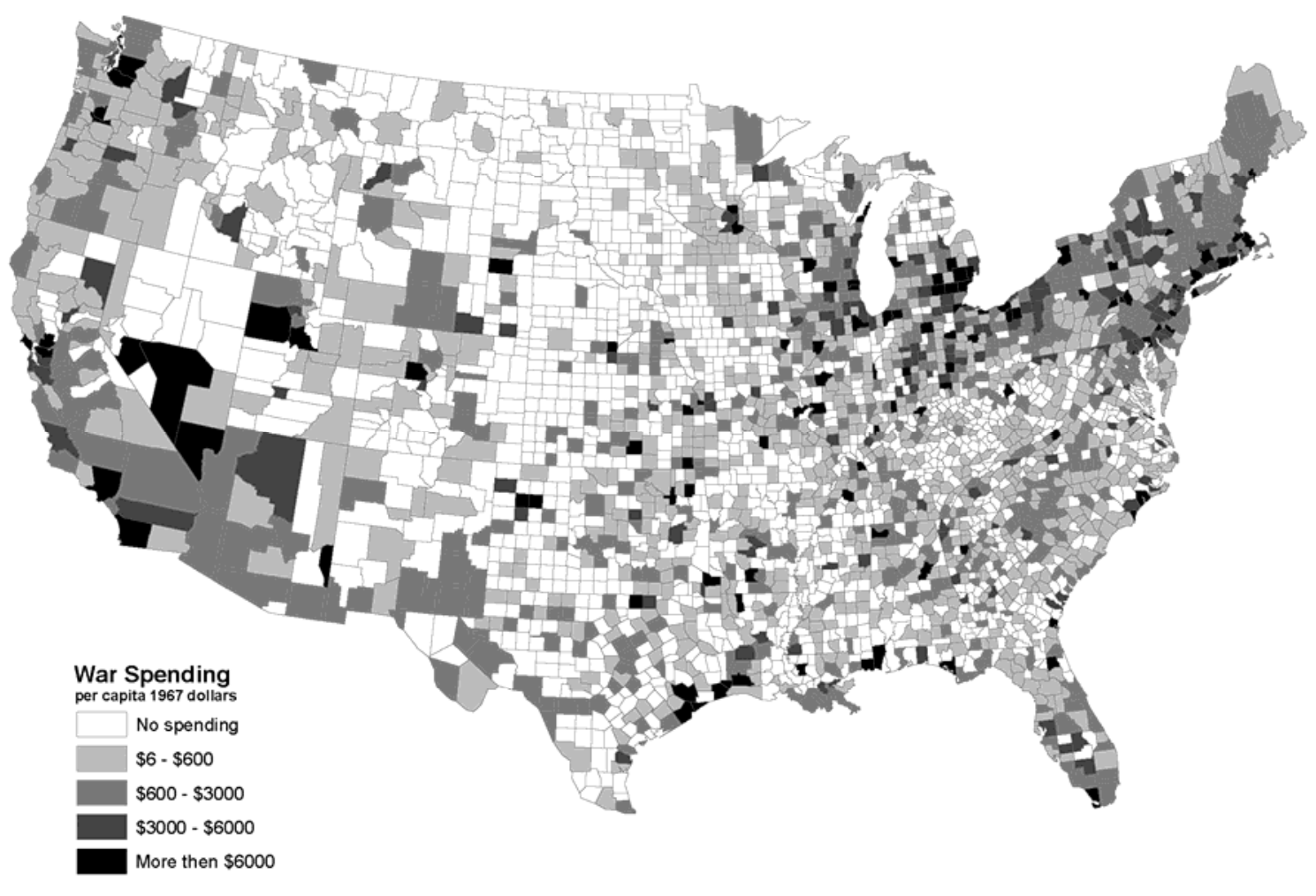


Figure 3: Scatter Plot of State Retail Sales Per Capita (1967\$) Growth Rate, 1939-1948

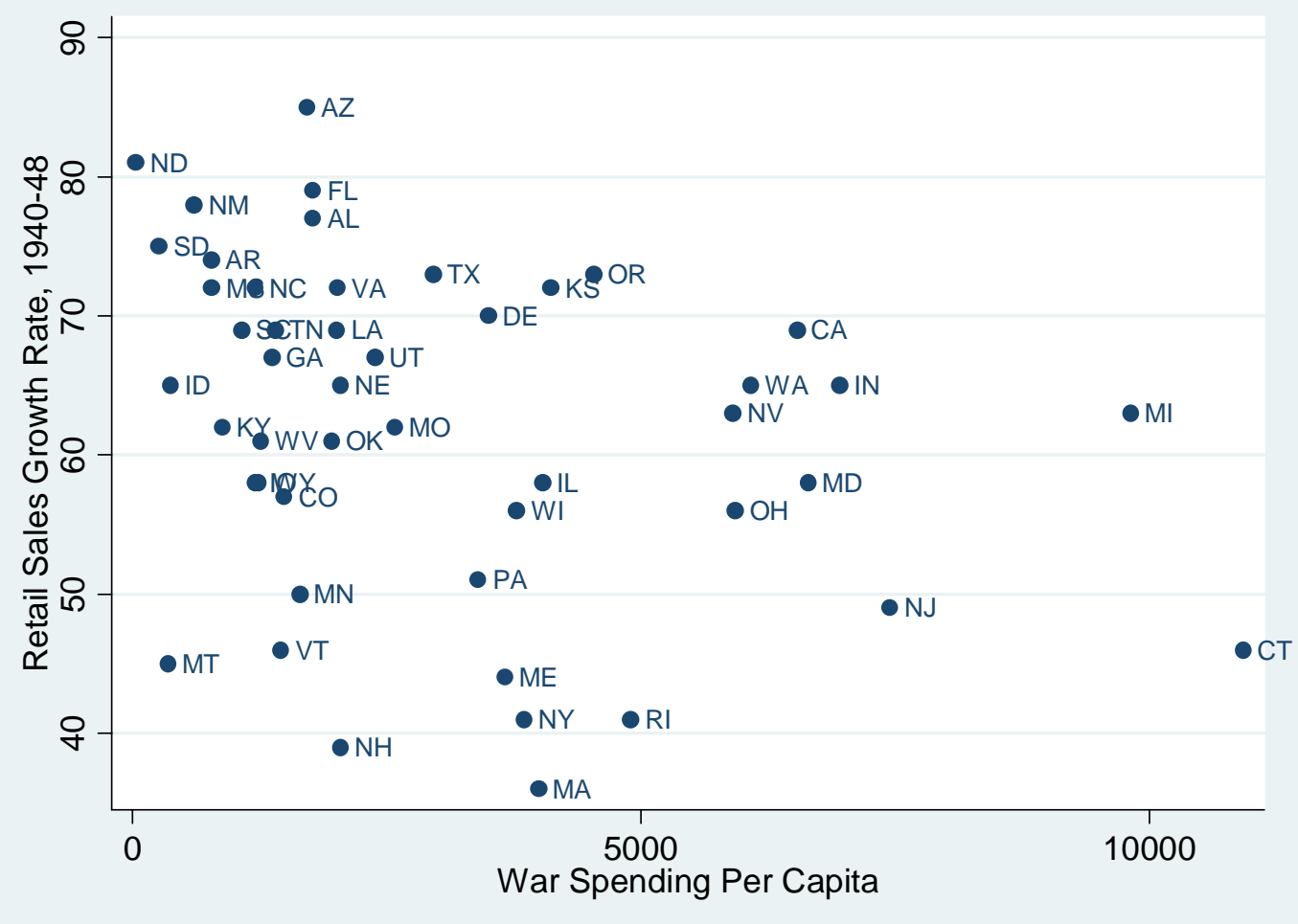


Figure 4: Per Capita Retail Sales Growth, 1939-48

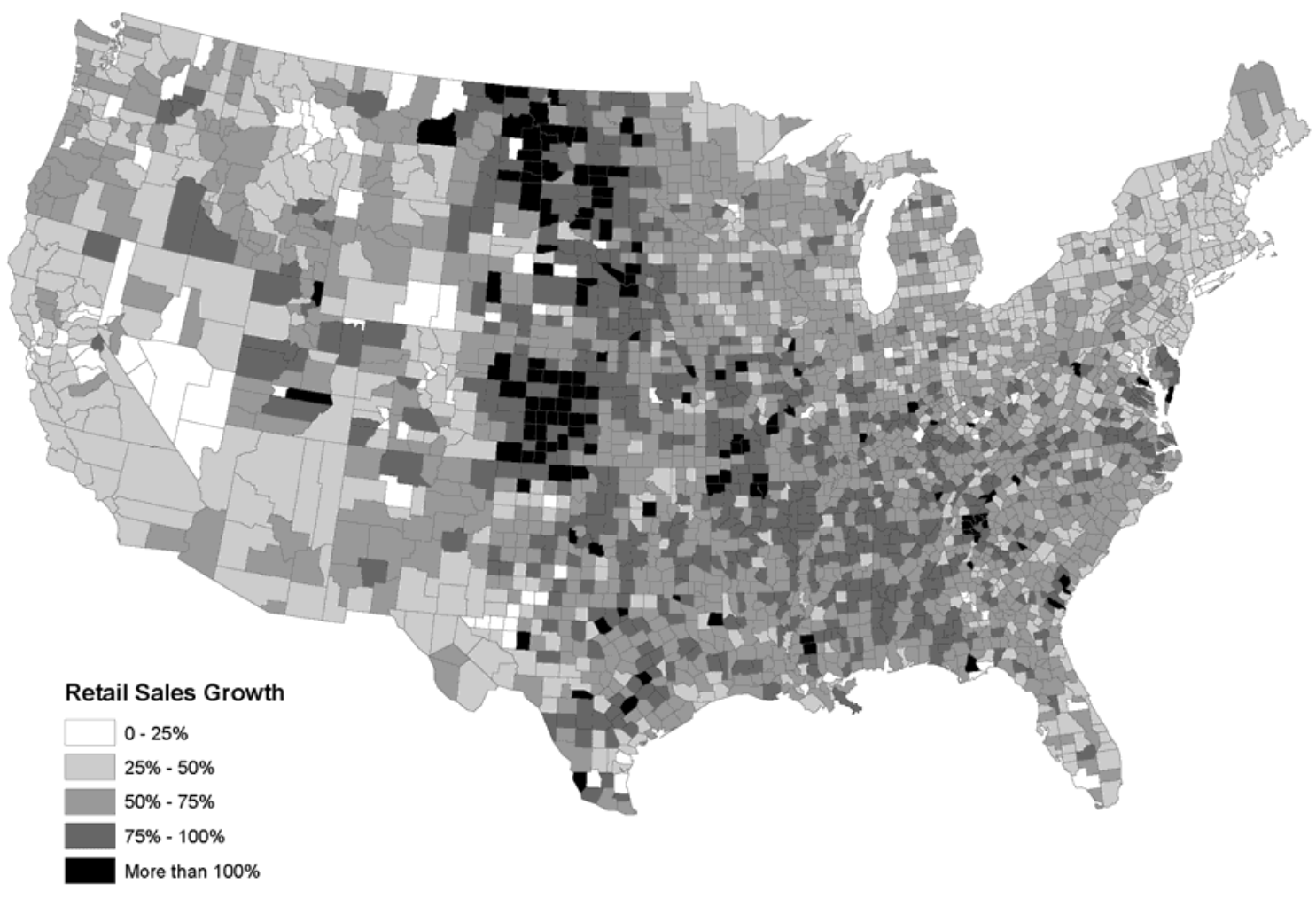

